\title{
The Norn Hildina Ballad from the Shetland Islands: Scandinavian parallels and attempts at reconstruction/translation
}

\author{
Mariano González Campo \\ St. Paul Gymnas
}

The Shetland Islands, together with the Orkney Islands, were until the nineteenth century a remarkable reservoir of the so-called Norn language, an extinct insular variety of Old Norse closely related to Icelandic and, specially, Faroese. Norn was preserved in these North-Atlantic British islands in form of single words, proverbs, or prayers. However, the longest and most complete text in Norn is the Shetlandic Hildina Ballad, collected on the small island of Foula in 1774 by George Low and consisting of thirtyfive stanzas. In this article I intend to offer a comparative approach to this Norn oral text refering to its Scandinavian parallels and the attempts at reconstruction and translation carried out by several scholars such as Marius Hægstad, Sophus Bugge, William G. Collinwood, Norah Kershaw, or Eigil Lehmann.

Keywords: Norn language; Old Norse literature; reconstruction; Scandinavian balladry; Shetland Islands; translation

Eit lukkeleg tilfelle hev berga for oss den eller den visa som elles vilde ba vore burtkomi.

Knut Liestøl (1937)

"Norn ballad deserves recognition, says linguist" stated the newspaper The Orcadian on January 3, 2008 (p. 12). This headline was due to the then recent publication of Gaeme Davis' book The Early English Settlement of Orkney and Shetland (2007), where this British linguist tried to prove, among other things, that there was a Saxon settlement in both the Orkney and Shetland Islands from as early as the fourth century AD. According to Davis, this early Saxon 
settlement in the (now) Scottish islands had an important influence on the language and culture developed there by Old Norse newcomers, i.e. the speakers of what later was to be called Norn, a word which seems to have its origins in the adjective norronn (Hægstad 1910: 53; Indrebø 1951: 279; Barnes 1984a, 1984b, 1998, 2004). In his book, Davis devotes some eighteen pages (out of 132) to attempting a new approach to a long forgotten, and underrated, product of the North Atlantic oral culture: the Hildina Ballad, the Norn ballad which "deserves recognition".

The Orcadian's headline is quite striking because it is only now, almost two centuries and a half after that Shetlandic ballad was written down, that it has attracted some attention. The rather familiar story about an abducted princess and the ensuing conflict, although unique in its form and language, had so far usually gone quite unnoticed even in specialized academic journals.

In this article, then, I will try to offer a brief introduction to the Hildina Ballad as well as an overview of the Scandinavian parallels and attempts at reconstruction and translation that some reputed scholars have tried to make since the nineteenth century. Thus, my aim is not only to offer an introduction to this Shetlandic oral story, but also to substantiate Davis' claim that the ballad deserves recognition, as well as further research in order to understand better both its particular origins and the dynamics of the transmission, composition, and interpretation of oral literature within a general folkloric context.

\section{The Hildina Ballad: Context of discovery}

Of the 6,289 islands that form the British archipelago (Moore 2005: 1), only one of them enjoyed the privilege of preserving one of the most interesting documents for the study of Scandinavian balladry: the island of Foula (from Old Norse Fugloy), located twenty miles west off Mainland Shetland and inhabited nowadays by some twenty-five people.

From the point of view of ballad studies, this remote spot in the North Atlantic was put on the map in 1774, when a Scottish clergyman named George Low $^{1}$ started a tour around the Orkney and Shetland Islands to collect information on several matters related to natural history. However, many other

\footnotetext{
${ }^{1}$ George Low was born in Forfarshire (now Angus, in the east coast of Scotland) in 1747 and died 49 years later, in 1795. He was appointed reverend in Stromness, in the Orkney Islands.
} 
folkloristic, ethnographical, or simply antiquarian issues also attracted Low's restless attention. His four-month long trip (from May 4 to the beginning of September) resulted in a posthumous book entitled A Tour through the Islands of Orkney and Schetland Containing Hints Relative to their Ancient, Modern and Natural History Collected in 1774, edited by John Anderson in Kirkwall in 1879. ${ }^{2}$ As Low himself narrates in the part of the book devoted to his visit to the island of Foula (Low 1879: 95-117), he arrived there on July 4 and departed on July 11. During this one-week stay in the so-called "Bird Island", Low collected most of his material regarding the Norn language. This included, for example, a version of the Lord's Prayer (somewhat different to its Orcadian counterpart published by James Wallace in A Description of the Isles of Orkney, 1683), a list of thirty Norn words with their English translation, and, last but not least, the only extant version of the now called Hildina Ballad, which was then titled The Earl of Orkney and the King of Norway's Daughter: A Ballad. Unfortunately, George Low did not have any knowledge of the Norn language, so his transcription of the ballad has a good amount of misunderstandings and, probably, gaps. Moreover, Low was not a trained folklorist and studies in oral tradition had not developed yet in his time. Therefore, it would be absurd to expect from him a ballad written down or registered following highly skilled methods, such as the ones suggested by Ruth Finnegan's Oral Traditions and the Verbal Arts: A Guide to Research Practices (1991). Nevertheless, Low does offer us some useful - if scant - glimpses of information concerning the discovery of the Hildina Ballad. As he points out:

The following song is the most entire I could find, but the disorder of some stanzas will show that it is not wholly so. The subject is the strife between a King of Norway and an Earl of Orkney, on account of the hasty marriage of the Earl with the King's daughter in her father's absence. Here it is worthy to be observed that most of the fragments they have are old historical Ballads and Romances, this kind of poetry being more greedily swallowed and retentively preserved in memory than any others, and most fitted to the genius of the Northerns. In this Ballad I cannot answer for the ortography. I wrote it as an old man pronounced it; nor could he assist me in this particular. This man (William Henry, a farmer in Guttorm, in Foula) has the most knowledge of any I found; he spoke of three kinds of poetry used in Norn, and repeated or sung by the old men; the Ballad (or Romance, I suppose); the Vysie or Vyse, now commonly sung to dancers;

\footnotetext{
${ }^{2}$ The book was reprinted in 1978 by Melven Press (Inverness) without the original introduction. This entailed a remarkable loss of relevant information.
} 
and the simple Song. By the account he gave of the matter, the first seems to have been valued here chiefly for its subject, and was commonly repeated in winter by the fire side; the second seems to have been used in publick meetings, now only sung to the dance; and the third at both. Let it be remarked that the following ballad [i.e. the Hildina Ballad] may be either written in two long line or four short line stanzas. (Low 1879: 107)

In this short account, Low does not say a word about the Hildina Ballad's position among the three types of "poetry used in Norn" - or maybe it was William Henry who did not provide the information. Was it considered a ballad or a romance? Was it considered a vysie or a vyse (cf. Old Norse visa)? Or was it considered a song? On the other hand, his statement —or maybe again William Henry's ${ }^{3}$ - that the Hildina Ballad may be either written in two long-line (couplet) or in four short-line (quatrain) stanzas can be quite misleading, as couplets and quatrains use different methods of composition concerning rhythm and rhyme. It goes without saying that this poses serious problems when one tries to reconstruct the Hildina Ballad. Scant as it may be, however, this small piece of information is enough to bring the image of Faroese ballads to our minds and allow us to make some comparisons with them (cf. Thuren 1902, González Campo 2008).

After the transcription of the ballad, Low (1879: 113-114) gives a summary of its contents, something which comes as a useful guideline to any attempt at translating and/or reconstructing it:

A literal translation of the above I could not procure, but the substance is this: - 'An Earl of Orkney, in some of his rambles on the coast of Norway, ${ }^{4}$ saw and fell in love with the King's daughter of the country. As their passion happened to be reciprocal, he carried her off in her father's absence, who was engaged in war with some of his distant neighbours. On his return, he followed the fugitives to Orkney, accompanied by his army, to revenge on the Earl the rape of his daughter. On his arrival there, Hildina (which was her name), first spied him,

\footnotetext{
${ }^{3}$ As Rendboe (1993) remarks, it should be considered that, as stated in the original (not John Hunter's) introduction to A Tour through the Islands of Orkney and Schetland, William Henry drank a certain amount of spirits while reciting the ballad. This might have affected both the recital and the explanations he gave concerning the oral tradition in Foula.

${ }^{4}$ As Hægstad (1900: 31) remarks, in this summary Low gives data that are not in the ballad or that are told there differently.
} 
and advised her now husband to go and attempt to pacify the King. He did so, and by his appearance and promises brought the King so over as to be satisfied with the match. This, however, was of no long standing, for as soon as the Earl's back was turned a courtier, called Hiluge, took great pains to change the King's mind, for it seems Hiluge had formerly hoped to succeed with the daughter himself. His project took, and the matter came to blows; the Earl is killed by Hiluge, who cut off his head and threw it at his lady, which, she says, vexed her even more than his death, that he should add cruelty to revenge. Upon the Earl's death, Hildina is forced to follow her father to Norway, and in a little time Hiluge makes his demand to have her in marriage of her father; he consents, and takes every method to persuade Hildina, who, with great reluctance, agrees upon condition that she is allowed to fill the wine at her wedding. This is easily permitted, and Hildina infuses a drug which soon throws the company into a dead sleep, and after ordering her father to be removed, set the house on fire. The flame soon rouses Hiluge, who piteously cries for mercy, but the taunts he had bestowed at the death of the Earl of Orkney are now bitterly returned, and he is left to perish in the flames.'

Such is the subject of the Ballad, which might have been built on a true story, tho' now lost. It, however, shews the genius of the people, that tho' they were cut off from the rest of the world they had amusements, and these correspondent to the manners of the Northerns, among whom nothing was more common than the recital of the acts of their fathers. Most or all of their tales are relative to the history of Norway; they seem to know little of the rest of Europe but by names; Norwegian transactions they have at their fingers' ends.

The fact that, as Low himself claims, "most or all of their tales are relative to the history of Norway" makes us think that the Hildina Ballad might have a Norwegian origin. Furthermore, the action taking place in Orkney makes it quite feasible that the ballad as we know it nowadays was originally shaped there. Orkney was indeed a very productive cultural centre during the Middle Ages, as some poems composed by Orcadians —such as Bjarni Kolbeinson's Jómsvikingadrápa, Rögnvaldr Kali and Hallr Dórarinsson's Háttalykill, and the anonymous Málsháttakveði and Krákumál- show, not to mention the Orkneyinga Saga, one of the most important Icelandic documents concerning Orcadian history and politics (see, for example, Jesch 2005, 2006b; Renaud 1988). Its preservation in the Shetlandic isle of Foula might thus be due to fortuitous circumstances, not because that island was the original place of composition of the ballad —although the local culture might have reshaped or influenced it. 
According to its plot and motifs, the Hildina Ballad was included by Jonsson, Solheim \& Danielson (1978: 239) among the so-called "ballads of champions", representing the "blood revenge" type, ${ }^{5}$ with the following classification and description:

E97 Hildina-kvadet - Woman's lover killed by rival, and she takes revenge

Shetl

The earl of Orkney Islands takes Hildina, a king's daughter, to his home while her father is away. The king returns and pursues them to the Orkneys. Hildina advises the earl to become reconciled with her father. The earl tries to, but Hiluge, who wants Hildina for himself, prevents reconciliation. Hiluge kills the earl, cuts his head off and throws it on Hildina's lap. He then asks for her hand, and the king gives his consent and tries to persuade his daughter. Hildina gives in on the condition that she may serve the wine at their wedding. She gives all the men a sleeping-draught. They fall asleep, and Hildina has her father carried out of the house and then sets fire to it. Hiluge and his men lose their lives.

\section{The Hildina Ballad: Scandinavian parallels}

The fact that the Hildina Ballad was recited and written down in Foula does not necessarily mean that it is an original product from that or any of the other Shetland Islands. Despite the efforts of Jakob Jakobsen (1897, 1928-1932) and Hugh Marwick (1929), ${ }^{6}$ our data about the Norn language are so scarce that it is almost impossible to put the lexicon of the Hildina Ballad within the wider context of the set of Western Scandinavian dialects known as Norn, which were mainly spoken in the Orkney and Shetland Islands, but also in Caithness (Thorsen 1954) and the Hebrides (Christiansen 1938). Be it as it may, it seems quite clear that our ballad has a chiefly Scandinavian background concerning not only its language but also the plot and most of the motifs it uses. Although

\footnotetext{
5 The other "blood revenge" types of ballads of champions in The Types of the Scandinavian Medieval Ballad are: Ásmundur sterki, Tróndur Jógvansson, Virgar Berkilsson, Sjúrður av Nøríki, Svend af Vollersløv, Grimmars kvæði, and Snæúlvs ríma. It is interesting to note that, excepting Svend af Vollersløv, which also has Danish, Icelandic, and Swedish versions, the rest are only found in the Faroe Islands.

${ }^{6}$ An interesting criticism of the methodology used by Jakobsen in his Etymologisk ordbok over det norrøne sprog på Shetland can be found in Bugge (2005).
} 
some continental ${ }^{7}$ and Celtic ${ }^{8}$ parallels can be established as well, it is my aim here to focus on some of the medieval Scandinavian texts and oral traditions that may have helped to shape the Hildina Ballad, a story which, although it sounds quite familiar within det norrøne folkeviseumrådet, as Liestøl (1937) would put it, it is rather unique as it does not have any close counterpart among the 838 types of ballads registered by Jonsson, Solheim \& Danielson (1978).

Three main literary categories can be used here in order to try to establish the Nordic parallels of the Hildina Ballad:

a) the fornaldarsögur

b) Old Norse texts dealing with poetic issues

c) Scandinavian ballads 9

Of course, it would be extremely risky to state that those parallels were actually used by the composer/composers of our ballad, as there is no safe way to demonstrate it empirically, but at least they might give us a helping hand in exploring the Scandinavian background of the ballad and its place within a wider Nordic cultural context. If it is true that the Hildina Ballad is unique, it should also be crystal clear that unique is not a synonym for rare.

\footnotetext{
${ }^{7}$ For example, Kershaw (1921:219) states that "there can be little doubt that the subject of the ballad is the story of Hethin and Högni. After this, however, the narrative deviates from any other known version of the story. It would rather seem that - as in the German Kudrun - two stories, originally distinct, have been brought together in one poem."

${ }^{8}$ On the Celtic influence in the Hildina Ballad through motifs like "throwing of the head" or "king and goddess theme", see especially Baranauskiené (2007). Grüner-Nielsen (1939: 152, 163) also remarks the presence of Celtic elements in the ballad such as the theme of the everlasting battle or the use of the word glasburyon, which "synes sproglig afhængig af keltisk 'glastonbury'."

${ }^{9}$ The Orkneyinga Saga would deserve a chapter of its own as a possible historical source for some of the characters that might lie behind the plot of the Hildina Ballad. For example, would it be possible to consider Hildr/Ragnhildr - the daughter of king Hrólfr nefja of Norway, who married Rögnvaldr Mœrajarl according to Chapter 4 of the Orkneyinga Saga - a historical inspiration for the Hildina of the ballad? As the daughter of a Norwegian king, the mother of the legendary Göngu-Hrólfr (founder of Normandy) and the wife of an influential jarl in Orcadian politics, she had every chance to become an interesting character for medieval singers of tales.
} 


\section{a) Parallels in the fornaldarsögur}

The first scholar who tried to make some sense of the Hildina Ballad was Peter Andreas Munch. He did so by translating some words or sentences into Old Norse and Danish, as well as by pointing to some Scandinavian parallels back in 1839, i.e. well before Low's manuscripts about his tour of the Orkney and Shetland Islands were published by Joseph Anderson in $1879 .{ }^{10}$ Later on, other scholars such as Hægstad (1900, 1901), Kerwick (1921), or Grüner-Nielsen (1939) also tried to establish some parallels with other Scandinavian stories similar to that in the Hildina Ballad. Regarding the texts classified as fornaldarsögur, all the aforementioned scholars agree that the story of Högni and Heðinn, as it is known from the Heðins saga ok Högna (also called Sörla páttr ${ }^{11}$ ) is one of the most obvious parallels with our Shetlandic ballad. ${ }^{12}$ Chapters 7 and 8 of Sörla páttr show very close parallels with an important part of the plot of the Hildina Ballad. This is a summary of the story:

There was a king named Hjarrandi, who had a son named Heðinn. This son was a great sea-king and he pillaged all over the Mediterranean until twenty kings paid tribute to him. One day he met a beautiful woman sitting on a chair who called herself Göndul. She told him of Högni, and agitated him to test his strength against the northerner. Heðinn took three hundred men, and sailed both a summer and a winter until he arrived in Denmark in spring.

When the two men met they tested each other's strength and entered sworn brotherhood. As Heðinn was unmarried, Högni betrothed him to his daughter Hildr, his only child. Hildr's mother was Hervör. Heðinn soon met the beautiful woman again who asked him about what had happened since the last time. She gave him a magic potion and told him to crush Högni's wife with the prow of his ship and to kidnap Hildr. He did so and met the beautiful woman again. She gave him a new horn to drink and he fell asleep. In his dream, he heard Göndul say that she put him, Högni and their men under spells according to the wishes of Óðinn.

Högni hunted Heðinn and found him on an island named Háey (=Hoy, in the Orkneys). Heðinn offered to give everything back to Högni and to sail away

\footnotetext{
${ }^{10}$ However, Low's Hildina Ballad had already been published by James Headrick in 1808 , in the second editon of History of the Orkney Islands by Dr. Barry. This was in fact the text used by Munch.

${ }^{11}$ I follow Jónsson's edition (1954).

${ }^{12}$ At this point, it should be clear that by 'Shetlandic ballad' I mean a ballad recited and written down in the Shetlands, not necessarily a ballad which was originally composed there.
} 
to Serkland and never come back. Högni, however, declared that nothing could atone the betrayal that Heðinn had committed.

The two armies started to fight and even though they cut each other all over, they stood still fighting and fighting for 143 years, so strong were the spells of Göndul, until Óláfr Tryggvason arrived at the island.

The name Hildr, the kidnapping of Hildr by Heðinn, and the fight between Heðinn and the army of Hildr's father in the Orcadian island of Háey (=Hoy) are the most striking parallels between Sörla páttr and the Hildina Ballad.

Furthermore, another fornaldarsaga titled Illuga saga Griðarfóstra displays some interesting parallels as well. This is the synopsis of the story: ${ }^{13}$

The story begins in Denmark where there was a king called Hringr, the son of Skjöldr Dagsson. It lauds Hringr's qualities as well as those of his son Sigurðr. The mother was Sigríor, the daughter of Vilhjálmr of Valland.

Not far from where they lived there was a farmer called Sviði whose wife was Hildr and son Illugi. This Illugi played often with prince Siguror. The two boys became close friends and swore to avenge one another. However, the king had an incompetent advisor named Björn who was treacherous and cunning, but skilled in seiðr and a great warrior who ably defended Denmark for the king. Björn was jealous that Sigurðr loved Illugi so much, so he slandered Illugi in front of the king and the prince, but Siguror refused to believe him.

One summer, Siguror, Björn and Illugi went a Viking expedition to Scotland and Orkney. The pillaging was good, and in the autumn they steered home to Denmark. However, a great storm arose and they were driven away to large bay called Gandvík. In the bay it was cold and Björn asked Illugi to cross a fjord to fetch firewood. If he succeeded it would prove him a better advisor and he would get Björn's ring. Illugi, however, declined and said that he would go for wood anyway.

When he had crossed the fjord, he found a cave and soon its inhabitant came. It was a troll woman named Gríor. She could not be called beautiful at all. When Illugi said that he came searching for fire, she replied that he would get none unless he said three truthful words and slept with her daughter. The daughter was stunning and Illugi immediately fell in love with her. The truthful words, he chose to say were that she was hideous, the hall was beautiful and so was the daughter. Gríor said that since he preferred the daughter to her, he could go to bed with the girl. Illugi was surprised that she was not enjoying the act, and soon he found out why because Gríor grabbed him by the hair, put a knife to his

\footnotetext{
${ }^{13}$ According to Jónsson's edition (1954).
} 
throat and said that she would kill him for seducing the girl. However, when Illugi showed no signs of fear, she asked him to go back to bed remarking that she had never met anyone less afraid of dying. Grírr said that he would have the girl whose name was Hildr, and then she told him her story:

She said that there was a king Áli in Álfheimr whose queen was Álfrún. Their daughter's name was Signý and she was a very able girl. She was married to a king named Eirikr who died during an expedition in the west, leaving her with a very beautiful daughter named Hildr. Signý then returned to her father, but the mother soon died and the father remarried with a woman named Grimhildr who was just as evil as she was beautiful, and so were her daughters that she had before marrying king Áli. Rumours began to spread in the kingdom and as soon as a man disappeared mysteriously this was attributed to Grímhildr. Grímhildr murdered the old king by poison, became the ruler and soon her tyranny had laid the whole kingdom waste. She then banished Signý and her daughter Hildr from the kingdom putting a curse on them that they had to live alone in a cave. All the men who saw Hildr would fall in love with her, but Signý would murder them, and every night seven sisters would maim and mutilize her. In this condition they would live until she found a man who was not afraid of dying.

Gríor said that she was Signý and as he had delivered them from the spell after eleven years, Illugi would marry her daughter. Then seven giantesses arrived with short swords and attacked Grírr cutting her in the body and in her heart. Illugi threw himself into the fight to defend Griorr, killed all seven of them and burned them in the fire.

Griorr gave Illugi gold and he returned to the ships with fire. The other men were glad to see him, but Björn slandered Hildr and said that she was an evil troll. Sigurðr told Björn to keep quiet. Later at night Björn disappeared and in the morning they found him dead hanging from the mast of the ship. This was how Grior punished him for calling her daughter a troll.

Siguror then sailed back to Denmark with the ships laden with booty. Later, king Hringr died by illness and Sigurðr inherited Denmark.

Signý came to Denmark to join them and was well received by Illugi and Hildr. Illugi told Siguror everything about Signý and Siguror decided to marry her. They had many children and lived long. But Illugi lived longest even though he and Hildr never had any children.

In this case, the most obvious parallels with the Hildina Ballad are the name Illugi, the name of Illugi's bride (Hildr), and the character of the treacherous royal adviser (Björn). However, it is interesting to note here that in the Shetlandic ballad Hiluge (=Illugi) takes the role of Björn, while Illuge comes closer to the role of the Earl of Orkney. 


\title{
b) Parallels in Old Norse texts dealing with poetic issues
}

In this context, I must emphasize the existing relationships between the Hildina Ballad and pedagogic or instructional texts such as the Orcadian Háttalykill and Snorri Sturluson's Skáldskaparmál and Háttatal, where allusions to the Hjaðningar legend —included in the aforementioned Sörla páttr as the fight ensuing from Hildr's abduction by Heðinn - can be found (Helgason \& Hotsmark 1941; Pálsson 1984, 1998; Faulkes 1991, 1998; Jesch 2006b).

Stanza 23 of Háttalykill enn forni makes the following mention to the Hjaðningar legend (Helgason \& Holtsmark 1941: 26, not normalized text):

\author{
Hver red billdi at nema? \\ Hveir dagleingis beriast? \\ Hverir sijd arla settast? \\ Hverir siolingum atte? \\ Hedin red billdi at nema \\ Hiadnengar a beriast \\ peir sijd arla settast \\ Saman billdr lidi atte.
}

The name of Hildr and the allusion to her abduction by Heðinn are the most significative parallels with the Hildina Ballad according to Sörla páttr's more extended version of the everlasting battle of Hjarningavíg. As Jesch (2006b: 2) points out, "the question-and-answer form of the stanzas (unique in this poem) may suggest that some instruction in this myth [i.e. the Hjaðningavig] was needed. There is later evidence, in the form of the Hildina ballad, to support the Orkney connection, and indicating that a version of the story was later known throughout the Northern Isles."

Chapter 50 of Snorri Sturluson's Skáldskaparmál deals with the Hjaðningavíg, first giving a good summary (cf. Sörla páttr) of the situation that led to the battle and proceeding afterwards to reproduce five stanzas from Bragi skáld's Ragnars drápa loðbrókar, where poetry is used to narrate the battle. The third stanza, for example, says the following (Faulknes 1998: 73, with minor adaptations):

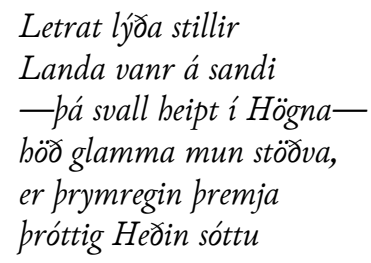


beldr en Hildar svíra

bringa peir of fingu

On the other hand, in stanza 49 of his Háttatal, Snorri Sturluson alludes again to the Hjaðningar legend in this way (Faulknes 1991: 23, with minor adaptations):

\section{Hjaldrremmir tekr Hildi (bringr brestr at giöf) festa, bnigr und Högna meyjar hers valdandi tjald; Heðins mála býr buílu Hjálmlestanda flestum, Morðaukinn piggr meki Mund Hjaðninga sprund}

\section{c) Parallels in Scandinavian ballads}

Inspired by Hægstad (1900, 1901) and Grüner-Nielsen (1939), and based on Jonsson, Solheim \& Danielson's The Types of the Scandinavian Medieval Ballad (1978), I have been able to identify up to fifty-three types of Nordic ballads (out of 838) which show several parallels with the Hildina Ballad concerning plot and/or motifs. ${ }^{14}$ Here is a list of those types of ballads together with a brief summary, origin, and classification code according to Jonsson, Solheim \& Danielson's handbook. A few remarks are also in order. The parallels in plot and/or motifs are in bold type: ${ }^{15}$

${ }^{14}$ Grüner-Nielsen (1939: 159-165) identified four well-known motifs in the Hildina Ballad: Medbejler og ond Raadgiver (rivals and the evil counsellor), det afbuggede Hoved (the chopped head), Indebrending (killing a person burning him inside a house), and den evige Kamp (the everlasting battle).

${ }^{15}$ Note on the symbols and abbreviations used in this list:

$+=$ a closer relationship to the Hildina Ballad (according to plot and/or motifs)

- = a more distant relationship to the Hildina Ballad (according to plot and/or motifs)

Var. = variation

$\mathrm{D}=$ Denmark $\quad \mathrm{N}=$ Norway

$\mathrm{F}=$ Faroe Islands $\quad \mathrm{S}=$ Sweden

$\mathrm{I}=$ Iceland 
(A) Ballads of the Supernatural:

+ A41 Ribold og Guldborg (D, I, N, S): A knight persuades a maid to leave the country with him. They are pursued by her family, and a fight ensues during which the knight kills her relatives. At this she forgets that he has forbidden her to use her name during the fight and calls out to him. He is then mortally wounded. He takes her to his home where he dies. She (and his mother) dies from sorrow.

+ A42 Hildebrand og Hilde (D, S): A girl tells the tragic story of her life. She escaped from home with a knight. Her relatives pursued them, and the knight requested her not to mention him by name during the ensuing fight. When he was about to kill her youngest brother she forgot her promise and called his name, whereupon her betrothed was killed. She was severely punished by her family.

(C) Historical Ballads:

- C10 Herr Lavrents og Bengta Sunesdatter (D): The Swedish judge Lars loves Bengta, who has been placed in a convent* by her family. Lars abducts her and takes her to Norway where they marry. After some years Lars falls ill. He calls for his wife, and before he dies he advises her to return to her brother in Sweden. When Bengta returns her brother is very cold towards her at first, but he changes his mind and promises to share his estate with her. (Var.: She rejects his offer and enters a convent.)

$\left[{ }^{*}\right.$ Cf. Hildina Ballad: in a glas buryon.]

- C15 Magnus Algotsøn (D, N, S): Torstein Davidsson arranges for his wedding with Ellensborg, who is loved by Folke Algotsson*. Folke rides to her home. His arrival is announced by a page-boy. Ellensborg covers her head, but Folke recognizes her by her eyes as soon as he enters the room. After a short talk (Var. D, N: in which he reminds her that she once promised herself to him) he takes off with her behind him in the saddle. The page-boy tells Torstein Davidsson what has happened. D, N: Torstein follows Folke with an escort. A fight ensues, and Torstein loses (Var. D: he is killed)

$\left[{ }^{*} \mathrm{Cf}\right.$. amorous triangle among Hiluge, Hildina, and the Jarl of Orkney in the Hildina Ballad. $]$ 
(D) Ballads of Chivalry:

- D3 Brud og bejler (D): A maid sees Erik, her suitor, approach and asks her family to bid him welcome. They refuse, and she goes out herself and greets him, asks him to stay and offers herself in marriage. They get engaged. Var.: Erik has to fight for her.

+ D18 Peder bjemforer sin jomfru (D): Peder breaks into a maid's bower at night and promises her a wonderful existence in the land of bliss, if she will only become betrothed to him. Then he takes her to his ship and they sail to his father's country where they celebrate their wedding.

- D27 Klerks kveði (I): A cleric from the pope's court travels widely. A king's daughter invites him to her table. When they get into bed she warns him of her father. He then persuades her to come with him to his own country. The king and the queen wake up late to find their daughter gone. The king writes a letter to the Sarracens' country requesting that they be burnt.

- D35 Morten Venstermand (D): Morten's betrothed has been taken to a convent by her seven brothers in order to prevent her marriage. The king gives Morten permission to take her out of the convent ${ }^{*}$. Morten persuades his uncle to help him ${ }^{* *}$, and together they get the girl out. They invite the king to the wedding.

$\left[{ }^{*}\right.$ Cf. Hildina Ballad: our glas buryon burttaga.]

$\left[{ }^{* *}\right.$ Cf. Hildina Ballad: for frinda sin spir de ro.]

- D36 Herr Mortens klosterrov (D, I): Morten is sent abroad by his family because he wants to marry a penniless girl. When he returns the girl is in a convent. Morten decides to get his betrothed out of convent ${ }^{*}$ and asks for help and advice from his brother** (I: servants). He pretends to be dead (D: and his brother takes him to the convent where the girl is). While his betrothed is supposed to watch over him the body he takes her away. All the other nuns wish that such an angel would come for them, too.

[ ${ }^{*}$ Cf. Hildina Ballad: our glas buryon burttaga.]

$\left[{ }^{* *}\right.$ Cf. Hildina Ballad: for frinda sin spir de ro.]

- D37 Herr Karl på ligbåre (D, N, S): Sir Karl asks his mother to advise him on how to get the girl he loves (Var. D, N, S: out of the convent). She tells him to pretend to be dead and to send for the girl to watch by the corpse. She comes, and in the presence 
of what she thinks is a dead man she admits to loving him. At this Karl gets up from the bier and gives orders for their wedding to be prepared. (Var. D, S: All the other nuns wish that such an angel would come for them, too.)

- D50 Vilgår hertugson (N): Vilgår and Signe have pledged their troth, but Signe's father makes her marry a king. During the wedding Vilgår arrives (Var. and pours out wine for all the guests until they get drunk and fall asleep). He then leaves with the bride on his horse.

- D59 Riddara kveði (I): A knight sees a beautiful lady in a tower and goes in to her. She tells him not to stay if he wants to keep his life, but he stays anyway and falls asleep by her side. He is awakened by the clamour of weapons. With the lady in his arms he fights his way out and rides off with her.

- D64 Rige herr Tord (D): Sir Peder and his daughter have a talk, and he asks her to stop mentioning Sir Tord. When she disobeys he beats her. The girl sends her brother to Tord to return his gifts and to tell him that she is dying. Tord comes over immediately and asks her how she wants her father to die. She does not want him punished if he will only allow them to get married. Their wedding ceremony takes place.

- D65 Riddar feller far til møyi (N): A conversation between two lovers is overheard by the girl's father. She advises her lover to fight, but if possible to save her father's live. After the fight the young couple leaves together.

+ D76 Skógarmanns kveði (I): An outlawed knight has been on a visit to his betrothed, but in the morning they must flee because her father is expected. They take a boat but are caught in a storm. They must swim ashore, and he loses his weapons. Three hostile knights approach and fight with the man. Armed only with an oaken cudgel he finally succumbs. That night the maid kills the three knights in revenge and then enters a convent.

+ D78 Herr Hjelmer (D, N, S): Hjælmer has seduced a maid (Var. D, S: She is the king's daughter. Var. D, N, S: He has also killed her father or Var. D: her uncle or mother). Hjælmer meets the maid's brothers who accuse him of seduction (Var. D, N, S: and manslaughter). Hjælmer kills all the brothers except one, Ole, who begs for his life. Hjælmer spares him, but is treacherously killed by him. Ole takes Hjælmer's head 
to his sister to show that her lover is dead. She stabs Ole to death (Var. D, N: poisons him). (Var. D: Ole gives his sister to Hjælmer in marriage)

- D140 Bejlekunsten [1] (D, S): A young man goes to his foster-mother (Var. S: mother) and asks for advice on how to court a maid. His mother tells him to dress well and to be polite and attentive to the girls.

- D158 Bóthildar kveði [1] (I): The farmer Pétur gives a feast for the king and his men. Logi, the groom, comes to Pétur and wants his daughter Bóthild. Pétur replies that this will not be for as long as he lives. Logi gives Pétur a cut with his sword, and Pétur promises him his daughter in marriage. Bóthild wakes up and wonders if no one can help her. Then she kills Logi herself. She enters a convent.

+ D159 Bóthildar kveði [2] (I): The king hears Bóthild sing and sends for her. She comes with her brother who is killed when he will not give his sister to the king. Bóthild wants to take vengeance. She asks her maidservant (Var. I: foster-mother) to mix a poison-draught and makes the king drink her health. He dies and Bóthild enters a convent.

- D161 Ridder Stig og skottekongens datter (D): Sir Stig sails to Scotland and stays there for some time. One day he sees the king's daughter on her way to church. He pretends to be a poor fisherman and she tells him who she is. He is happy to have found her and takes her to his ship. He sails home to Denmark and marries her.

- D163 Palle Bosøns dod (D, F, N, S): Palle finds out from a servant that the girl he loves is going to church. He stops her carriage and takes her to his home in spite of her warnings. Shortly after they have got into bed, her betrothed (Var. F, S: her kinsman, the king, Var. N: her father) arrives, and Palle is killed. (Var. N: after having slain his bride's betrothed, Var. N: and father) (Var. F: Before he is killed, Palle asks his bride to have the two sons she will bear him take revenge) (Var. D: She marries her betrothed, Var. D, N, S: She refuses to marry him and enters a convent.) (Var. D, N: She has a child by Palle, Var. N: and dies in child birth) (Var. S: She says that the child she will have by Palle will revenge its father. Var. F: Palle's two sons grow up and revenge him)

- D172 Knud af Borg (D, F, I, N): (N: A maid has two suitors, the king and Knud af Borg. She chooses Knud. F: The king hears about Knud's beautiful wife and goes to visit Knud to look at her.) The king goes to Knud's wedding (D, I: Knud invites the king in spite of his bride's warnings. F Var. N: The king challenges Knud to defend his 
bride.) The king kills Knud (D: orders his men to do it). The king takes the bride to bed with him, but she makes him promise not to touch her the first few nights. Once he falls asleep she kills him. (Var. F: Before going to bed with the king Knud's widow arranges a funeral for her husband. By the grave she kills the king.) (Var. I: She dies from sorrow.)

- D222 Brøðurnir (F): Steffan goes to his brother Roland's house and is met by Roland's wife, Hilda. She says that Roland will be away until Christmas. She and Steffan spend the night together. When Steffan wakes up Roland stands by the bed and asks what his brother is doing there. Steffan replies that Hilda was as willing as he was. Hilda gives Steffan a coat of mail and the two men fight. They are both killed.

- D236 Arne og den untrue bruri hans $(\mathrm{N})$ : Arne's mother tells him that his betrothed has a lover, Jonas. In order to find out if this is true Arne says that he is going away. His betrothed sends for Jonas at once. Arne surprises them and cuts off Jonas' head.

- D237 Bonde Høg og bustrus boler (D): Ebi declares his love to Sir Bonde's wife and offers her gold. She is pleased and wishes her husband were dead. Her maidservant reproaches her. Bonde listens to all this. Ebi returns from a love-meeting with Bonde's wife and meets the husband, who kills him. Bonde shows his wife her lover's severed head. The he takes the maidservant for his mistress.

- D238 Sigvord kongesøn (D): Sigvord, a king's son, takes Kirstin out of a convent and promises her to be faithful. She warns him that if he fails her it will mean his death. She lives with him as his mistress for many years. One day he comes home and tells her that he is engaged to a noble-woman. She gives him a beverage made from herbs, and he falls ill. He tries to be reconciled to make her save her life, but she lets him die.

- D241 Stolt Elins hevn (D): A knight conducts her bride home. Elin serves the wine during the wedding and later she hides in the bridal chamber. She hears the bridegroom tell his bride that Elin has been his mistress. The bride tells him he ought to have married Elin instead. When the man has fallen asleep Elin stabs him to death. She spares the bride and advises her to return to her father.

- D245 Herr Peders slegfred (D, F, N, S): Sir Peder is about to celebrate his wedding. He does not want Kirstin to go, but she decides to be there. She wears her best clothes and jewellery to the wedding. D, F, Var. S: The bride asks who she is and is told that Kirstin was Peder's mistress. D, F: She says that Peder ought to have married Kirstin instead. 
Var. D: Kirstin steals into the house at night. She stabs the bridegroom to death, but she spares the bride because of her kind words. Var. D, F, Var. S: Kirstin hangs herself in the orchard, and when Peder hears about this he takes his life. The bride dies from sorrow. N, Var. S: Kirstin sets fire to the house and both bride and bridegroom die.

- D247 Hyrde og ridderfrue (D, F, S): Sir Themme hears a shepherd sing a song which reveals to him that the shepherd is his wife's lover. Themme has the shepherd hanged at once (F: cuts his head off). D, F: He tells his wife what he has done. D: She gets furious and tells him that all her twelve sons are the shepherd's sons. F: She keeps him awake at night by crying over the shepherd. D, F: Themme kills his wife.

- D327 Hertugen af Skare (D): The king's son Woldemor abducts Hyllegierd from a convent and takes her to his country. His mother the queen will not give her approval to their marriage, and Woldemor goes away with his betrothed. The queen sends them poisoned wine. Woldemor drinks it and dies. The same night Hyllegierd is delivered of three children. She dies, and only one of the children survives.

+ D337 Alexanders kveði (I): Alexander raids King Hringur's country and abducts his daughter. The king comes with his navy to get her back. In the ensuing battle the king kills Alexander. When the king is going to take his daughter home she says that a young knight will revenge Alexander's death.

- D350 Magna dans (I): The king of Sweden surprises his daughter with her lover and kills him. The daughter gets a son, Magne. When Magne is twelve years old his mother tells him of his father's death and urges him to take revenge. Magne finds his grandfather and is refused damages for his father. He kills the king and two of his men. His mother summons the people to an assembly. Nobody dares accuse Magne, who becomes king after his grandfather.

+/- D352 Liden Engel (D, N, S): (D, N: Engel has eloped with Malfred against her family's will.) Engel and Malfred are told that her brother (S: Engel's rival for Malfred) is approaching. They take refuge in the nearest church, but the brother sets fire to it. Malfred gets out, but Engels dies. Var. D, N: Malfred has a son who wants to revenge his father's death. Var. D: He sets fire to his uncle's house and thus kills him in the way his father died. Var. D, N: He kills the uncle with his sword.

- D385 Tistram og jomfru Isolt (D): Var.: Tristran is about to enter the emperor's service. He is warned not to fall in love with Isolt. When he arrives at the court the emperor's 
daughter Isolt sees him and falls in love with him. They meet in secret, and Isolt's mother tries to stop this. (Var.: She intends to poison them, but the lovers refuse to drink. Var.: Tristan forces her to drink herself, and she dies). Tristan and Isolt escape together and get married. Var.: A woman is told (Var.: dreams) that her son and daughter will want to marry each other. She sends her daughter to be brought up by the emperor's wife. When her son Tristan is grown up he enters the emperor's service, but is warned not to fall in love with Isolt. When he meets her they fall in love anyway. They are told that they are brother and sister but still want to escape together. The emperor builds a tower and puts Isolt in it. When Tristan tries to get her out of there the emperor's wife poisons them, and they die in each others arms.

- D386 Tístrams táttur (F): Tristan and Isolt are in love, but his parents are opposed to a marriage between the two. They send their son to the king of Frakkland (France) with a letter asking the king to marry his daughter to Tristan, and to kill him if he refuses. Tristan has sworn to be faithful to Isolt and rejects the proposal. He is executed. When Isolt is told she goes to Frakkland, burns the king in his house, and dies from sorrow by Tristan's body.

\section{(E) Heroic Ballads:}

- E21 Jallgríms kveði [2] (F): Jallgrímur wants to try his strength in fight and is told about a mountain giant. He goes to find him. They fight, and Jallgrímur saves his life only by promising the giant his son when he gets one. The giant spares him and also gives him a magic sword which will help him in fights. Jallgrimur goes to Ireland to try to get the king's daughter. His proposal is scornfully rejected by the Irish king. In the ensuing fight Jallgrimur kills a number of the king's men as well as the king himself and his son. He marries the king's daughter. She bears him two sons. When the boys are twelve years old Jallgrimur tells them to go from Ireland to his father's country to fight the giant. The boys set out and manage to kill the giant. One of the boys marries a girl they find in the giant's castle. Both become rulers of the country.

- E39 Guttormur í Hattarmóti (F): Margreta marries Guttormur. They are invited to Margreta's parents. They go in spite of suspicions. (Var.: On the way their ship is caught in a storm, but Guttormur stops it by means of magic.) When they arrive, Margreta's mother, the queen, has Guttormur killed. Margreta gives birth to a son, whom she sends away so that he may be out of the queen's way. (Var.: She also has a daughter, and both Margreta and the daughter are killed by the queen.) The son, Magnus, wants 
to revenge his father's death. His father's sister Ata gives him advice, which helps him avoid his grandmother's attempts to poison him. He sets fire to the house, and she is burnt to death. Magnus then sets out against his grandfather. Helped by Ata's advice he subdues the wild animals watching his grandfather's castle, and then he kills him. He succeeds his grandfather as king.

- E54 Frendebavn (D): Ellind is married far from home (Var.: to the man who killed her father). After eight years she prepares a feast for her brothers. They are well received by Ellind's husband, but at night he kills them all in their sleep and offers Ellind their blood to drink. Ellind takes revenge by killing all her husband's sons (Var.: sisters and brothers) and offering him a drink of their blood*. Then she kills him too (Var.: and her child by him).

[*Note that Hildina pays Hiluge back in revenge with the same cruelty.]

- E55 Høgna táttur (F): Gudrun gets married to King Artala. She wants to take revenge for Sjúrður's death and invites her brothers to a banquet. Their mother Grimhild warns them, and they are also warned by a person they meet on the way, but they do not listen. They arrive and are invited to sit down at their sister's table. She has poisoned their drinks, but Høgne discovers this. Gudrun induces her son to strike Høgne, and Høgne gets up and kills the boy. Gudrun urges Artala to kill her brothers, she uses magic, and everyone is killed except Høgne. A warrior turns himself into a dragon and pours poison on Høgne, who feels that he is about to die. He asks an earl's daughter, Helvík, to sleep with him before he dies. He tells her that she will have a son. She must call him Høgne, and he will revenge his father's death.

- E56 Grimilds havn (D): Lady Kremold sends a message to her brothers and invites them to her home. Their mother warns them that Kremold means to betray them, and they are also warned by persons they meet on the way, but they do not listen. Kremold receives them well, but later she eggs her men on, and the feast ends in a fight.

+/- E80 Rings kveði (F): Ringur, son of King Valdimann of Girtland, goes to Sjóland to propose to the king's daughter. He is accompanied by Pætur the Dane. The king rejects Ringur's proposal contemptuously and kills some of his men. Finally a fight breaks out, and the king is taken prisoner. Ringur lets him go at his daughter's request, and then marries the daughter. Var.: While Ringur is away from home Sjúrour, the emperor of Saksland, arrives in Girtland to propose to Kristin, Ringur's sister. Her father, King Valdimann, asks Sjúrður to await Ringur's return to get his consent. Sjúrður threatens 
to take Kristin home as his mistress, and there is a fight. Valdimann is killed. Kristin tries to defend herself, sword in hand, but is finally defeated by Sjúrður's men and taken to Saksland. When she meets Sjúrður she falls in love with him, and they are married. Ringur returns to Girtland and finds what has happened. He goes to Saksland to take revenge for his father's death. In the ensuing fight Sjúrður is taken prisoner. Pætur the Dane wants to kill him, but Ringur prevents this and goes to see his sister. Sjúrour is set free, but Ringur takes their newborn son back to Girtland with him. He gives the boy the name of Valdimann after his father.

- E92 Ásmundr sterki (F): King Ásmundur goes to Gjøtland to propose to the king's daughter Elin. In the entrance to the castle he kills an ogre and saves its tongue. His proposal is accepted by the king, but a rival prince Karvilín of Sweden, arrives and claims to have killed the ogre. Ásmundur shows him the tongue. Karvilín challenges him to fight, and Ásmundur kills him. Then he goes to see Elin and wants to marry her, but she says that he must first defeat Karvilin's father, King Ranild. Ranild arrives with an army. Ásmundur kills nearly all of his men, but Ranild begs for mercy and is spared. Ásmundur marries Elin and takes her home. He receives tax from Sweden.

- E93 Tróndur Jógvansson (F): Sjúrður asks the king for his daughter Margreta's hand, but the king does not think him good enough. Sjúrður talks to Margreta herself, and she accepts him. Meanwhile another suitor, Tróndur Jógvansson, arrives and is accepted by the king, but Margreta does not want him. At the king's suggestion the two rivals fight, and Sjúrður kills Tróndur. Tróndur's father Jógvan arrives to revenge his son. Sjúrður and Margreta both fight him, and finally Sjúrður kills him although he begs for mercy. Sjúrður and Margreta are married, and Sjúrður succeeds Jógvan as king.

- E94 Virgar Bekilsson (F): Gyrðilin decides to propose to a duke's daughter, Hilda, although he is told that Virgar Bekilsson has already proposed to her. When Gyrðilin arrives he meets Virgar and challenges him to a fight. Virgar kills him and all his men except Aðal, who turns out to be Virgar's brother. Together they go to the duke's house to find Hilda, but she has been carried away by an ogre. Virgar and Aðal go to the ogre's cave. In the ensuing fight Aðal is devoured by the ogre before Virgar manages to kill it and save Hilda. He takes her home and marries her. Later Brandur arrives with his son to revenge Gyrðilin's death. After a long and violent fight Virgar kills Brandur, his son and all his men.

- E95 Sjúrður av Nøríki (F): Sjúrður, son of the king of Norway, and King Gion of Ireland both arrive to propose to the Princess Júli. She prefers Sjúrður, but Gion 
challenges him to a fight. Gion is killed. Sjúrður and Júli are married and return to Norway. They have two sons, one of them called Grimmar. Gion's father, King Ívar, goes to Norway to revenge his son. Sjúrður kills Ívar and decides that his son Grimmar shall marry Ívar's daughter Herga. Grimmar proposes to her, and she tells him to get the consent of her kinsmen first. While he is away an earl from Sweden proposes to Herga and is accepted. Grimmar returns during their wedding, kills the earl and marries Herga. The king of Sweden comes to revenge the death of his earl. In the fight he kills Grimmar, but the young champion Hilmir kills him. After a year Hilmir marries Herga.

- E96 Svend af Vollersløv (D, F, I, S): Svend af Vollersløv wants to marry Lissebet, but she chooses to marry Villiam. Svend is very jealous, and shortly after Villiam's wedding to Lissebet he kills him. Lissebet gives birth to a son and names him after his father. (Var. D, F, I, S): When young Villiam grows up his mother tells him who killed his father. He sends a message to Svend af Vollersløv to meet him at the assembly. Svend refuses to give Villiam damages for his father's death, and Villiam kills Svend. He tells his mother that his father is now revenged. (Var. D, F): Villiam seduces Svend's sister (Var. F: wife). Her brother (Var. F: father) arrives to take revenge. Villiam kills him (Var. F: spares his life after killing all his men). Villiam marries the woman he seduced.

+/- E98 Grimmars kveði (F): King Haraldur of Ongland goes to propose to Hilda, daughter of King Grimmar of Gardarike. King Grimmar is away at war. Haraldur does not wait to get Grimmar's consent, and he and Hilda return to Ongland and marry. Hilda gets three sons. Later Haraldur wants to visit Grimmar. He leaves his youngest son Gormundur at home and brings the two others. He helps Grimmar win a war, but while he is away Grimmar prepares to take his life. He gives Haraldur so much to drink that he falls asleep and then sets fire to the house. Haraldur and his sons are killed. Haraldur's men return to Gormundur and Hilda with the news. Later Hilda marries the emperor Sjúrður and gets the son Haraldur by him. Gormundur goes to Gardarike to revenge his father's death on Grimmar. (Var.: Grimmar tries to stop Gormundur's ship by magic). Grimmar and Gormundur fight, and both use magic against the other. Finally Gormundur defeats Grimmar but spares his life and sends a message to Hilda. She sends her son Haraldur to Gardarike, where he kills Grimmar. Gormundur succeeds Grimmar as a king, and Haraldur returns to Ongland.

-/+ E99 Sncúlvs rima (F): The king of Jorsaland is dying and decides that his younger son Magnus will succeed him because Grimmar, the elder, is a bad man. After a quarrel Magnus sends Grimmar out of the country. Later the two brothers propose to Svanhild, 
daughter of the king of Uppland. She chooses Magnus, and they are married. They return to Jorsaland and bring Svanhild's brother, who marries Magnus' sister. Grimmar, who is still in Uppland, and Svanhild's father lay plans to kill Magnus. The king invites him for Christmas. In spite of Svanhild's warnings Magnus accepts the invitation and goes to Uppland with two of his sons, leaving the third, Sniolvur, behind. Magnus and his men are given so much to drink that they fall asleep, and then Grimmar sets fire to the house. Magnus and his sons manage to get out of the burning house. They fight hard for their lives, but Grimmar kills them with treachery. Svanhild gets the news and urges Sniolvur to take revenge. Sniolvur goes to Uppland accompanied by his cousin Ringur. When they arrive they meet a man by the name of Harra-Svein who tells them that Grimmar celebrates his daughter's wedding. He helps them join the celebration in disguise. They put the lights out and Sniolvur manages to get away with the bride while Ringur gets involved in a fight. Sniolvur returns and helps him get out of the house. Then he puts fire to the house, and his grandfather, the king of Uppland, is burnt to death. Sniolvur and Ringur meet Grimmar and fight with him. Grimmar tries to kill Sniolvur by treachery, but Ringur saves him and kills Grimmar. Sniolvur returns to Jorsaland, and Ringur becomes king of Uppland.

+/- E140: Herr Hylleland henter sin jomfru (D, F, N): ${ }^{16}$ The king's daughter has been carried away by an ogress. The king promises to give his daughter to the man who can bring her back, and Hylleland volunteers. He goes to the mountain where the ogress lives, and she says he may spend one night with the princess, but in the morning he must lose his life. Hylleland sleeps with the princess, and in the morning the ogress arrives to kill him. Var. N: Hylleland kills the ogress and all her relatives. Var. D: Hylleland uses runic magic to make the ogress change her mind, release the princess and let them leave with rich gifts. Var. F: The princess and Hylleland make a wooden dummy which the ogress tries to kill instead of Hylleland. He laughs at her mistake, and this makes her relent. She lets them leave with rich gifts. When the king's men see

\footnotetext{
${ }^{16}$ It should be noted that this is the Danish version of the Norwegian Kappen Illugjen and the Faroese Kappin Illbugi. The name of the princess is Hillelille (little Hild) in the Norwegian version and Hilda in the Faroese one. In these ballads Illugjen/Illhugen comes close to the role of the Jarl of Orkney in the Hildina Ballad, whereas the king's evil counselor (Björn) plays the role of Hiluge in the Shetlandic ballad. These Danish, Norwegian, and Faroese ballads are closely related to Illuga saga Griðarfóstra (see, for example, Liestøl 1915 and Erlingsson 1975, with conflicting interpretations about the relationship between this fornaldarsaga and related ballads).
} 
them return they want to attack the ogress, but Hylleland defends her. Var. D, F, N: Hylleland and the princess are married.

- E162 (N): Venill fruva og Drembedrosi: A king remarries. His new wife, Drembedrosi, is of giant kin, and she wants to marry her brother to her stepdaughter Venill. She threatens to turn the girl into a barren tree if she does not accept. Venill is taken into the mountain to celebrate her wedding. She tries to postpone the ceremony by various means, and when it eventually takes place she pours out mead to the guests until everyone falls asleep. She sets fire to the house and escapes. When she gets back home she exposes her stepmother to her father the king, who kills Drembedrosi.

-/+ E164 Artal kongur i Atlandi (F): King Artal wants to ravage the country of king Gudmund. He learns magic from a witch and marries her. He goes to Gudmund's country, kills him, and returns home. Hákun, foster-son to Gudmund, sets out to get revenge. Artal and his wife try to stop him by a storm, but Hákun uses counter-magic and gets ashore. He kills Artal and the witch. Ringarálvur, brother of the witch, arrives to revenge his sister's death. He fights with Hákun, but they find out that they are brothers and make up. Ringarálvur goes to Atland to propose to Hilda, but she says she would rather marry the earl of Langalund. Ringarálvur kills the earl and forces Hilda to marry him. Holdi, the earl's father, wants to revenge the death of his son. In the ensuing battle Ringarálvur is victorious and kills Holdi and all his men. After this, Ringarálvur goes to a giant's cave. He fights with the giant, and by magic means Ringarálvur wins the fight. He kills the giant and takes his gold.

\section{(F) Jocular Ballads:}

- F23 Sorte Iver (D, F, N): Iver Black is derided (Var. F: is turned down by the woman he proposes to) because he is so black. He asks his mother how he might seduce a certain woman*, Kirsten (Var. F: the one who turned him down), and his mother advises him to pretend to be the clergyman. Dressed like the clergyman Iver is let into Kirsten's room and spends the night with her. In the morning he tells her who he is. Var. D, N: She asks him to stay, for he is not so black after all.

[* Advice from a relative also in the Hildina Ballad.]

- F24 Germand smed og prestens datter (D, I, S): Germand the blacksmith proposes to the clergyman's daughter, but she rejects him spitefully, saying he is too dirty. Germand 
asks his mother's advice*. She tells him to go to the clergyman's daughter disguised (Var. D: as a blind man, Var. I: as an old woman, Var. I, S: as a beggar). In this disguise Germand manages to get into the girl's bed and sleep with her. In the morning he tells her who he is. Var. D: She wants to marry him, but he says nobody will want her for a wife now.

[* Advice from a relative also in the Hildina Ballad.]

\section{The Hildina Ballad: Attempts at reconstruction}

George Low wrote down the Hildina Ballad from William Henry's lips without knowing the Norn language spoken in the Shetlandic island of Foula, nor any form of the Norn language for that matter. Moreover, it seems that the ballad was quite worn out when Low found it. All this led to several problems, for instance: words written down that maybe did not exist in Norn, a deficient phonetic transcription of the words pronounced by Henry, or a mistaken arrangement of the verses of the ballad. In other words, Low's - and the world's - only extant version of the Hildina Ballad is not a reliable document. For this reason, there were some early attempts to (re)elaborate a version closer to a supposed original by scholars such as Svend Grundtvig, Axel Olrik, Moltke Moe, or Sophus Bugge with the assistance of Jakob Jakobsen, a Faroese linguist specialized in the Norn language of the Shetland Islands. ${ }^{17}$ However, it was Marius Hægstad - the Norwegian author of the influential Vestnorske maalføre fyre 1350 - who took the lead in 1900 with the, so far, most comprehensive linguistic study of the Hildina Ballad, titled Hildinakvadet med utgreiding um det norske maal paa Shetland i eldre tid. In his study, Hægstad claimed that Low's main mistakes were: 1) Sometimes he divided one word into two or used fragments of a word as if they were independent (e.g. vanna ro instead of vannaro = vandaráð? vinaráð?); 2) Sometimes he created a word out of two independent words (e.g. elonden instead of elonden = i löndum?); 3) In some cases, he split a word in fragments and merged them into other words (e.g. vod lerdin instead of

\footnotetext{
${ }^{17}$ Some interesting letters sent by Bugge either to Jakobsen or to Olrik about his plans to publish a more reliable version of the Hildina Ballad can be found in Kruken (2004, vol. 1, p. 212; vol. 2, pp. 562, 600, 608; vol. 3, pp. 738, 740, 743. The pages refer to the parts of the letters where the Hildina Ballad is explicitly alluded to).
} 
vodler din = völlr/völlin pinn?); and 4) In many instances, Low arranged the verses of the ballad in a wrong way by putting a word in the previous or following verse or by putting a verse in the previous or following stanza.

Although Hægstad managed to produce a linguistically much more reliable interpretation of the Hildina Ballad than Low, in 1984 the Norwegian scholar Eigil Lehmann tried to go one step further and normalize the ballad, drawing inspiration from V. U. Hammershaimb's etymological approach to the Faroese language. ${ }^{18}$ As Lehmann (1984: 7-8) points out:

So tidleg som 1808 var visa [i.e. Hildina Ballad] prenta av ein James Headrik [sic], i 1838 av nordmannen P.A. Munch. Andre som hev arbeidt med kvædet er dansken Svend Grundtvig, nordmannen Sophus Bugge, færøyingen Jakob Jakobsen, nordmannen Moltke Moe og dansken Axel Olrik. Desse hev mest bala med å føra kvædet attende i gamalnorrøn form. Ei “attføring” etter Axel Olrik frå 1898 er å finna i ei utgreiding um kvædet av dansken Hakon Grüner-Nielsen i heidersskriftet til Gustav Indrebø 1939. Men mætaste arbeidet er gjort av normannen Marius Hægstad i boki 'Hildina-kvædet', som kom ut år 1900. Han hev like vel ikkje gjort nokon freistnad på "attføring" so som hine.

Ein freistnad som ikkje er gjord, men som me hev teke oss fyre i dette arbeidet, er å føra kvædet yver i ei skriftform som knyter til norrøn tradisjon men er serleg tilmåta til målføret - i so måte eit sydestykke til det som V.U. Hammershaimb gjorde med Færøymålet.

In the following Table 1 we can see a comparison of Hægstad's and Lehmann's attempts to reconstruct the Hildina Ballad from Low's original version.

\footnotetext{
${ }^{18}$ Although Faroese had a rich oral tradition, it lacked a consistent written form —or any important form of written language for that matter - until Hammerhaimb, and later Jakob Jakobsen, tried to create a normalized written Faroese based on several etymological guidelines mainly inspired by Icelandic purism. A couple of interesting anthropological approaches to the normalization process of modern Faroese can be found in Wylie \& Margolin (1981, esp. Chapter 4) and Nauerby (1996).
} 
Table 1. Hildina Ballad: attempts at reconstruction

\begin{tabular}{|c|c|c|}
\hline $\begin{array}{c}\text { GEORGE LOW } \\
(1774)\end{array}$ & $\begin{array}{l}\text { MARIUS HÆGSTAD } \\
(1900)\end{array}$ & $\begin{array}{c}\text { EIGIL LEHMANN } \\
(1984)\end{array}$ \\
\hline $\begin{array}{l}1 . \\
\text { Da vara Jarlin d'Orkneyar } \\
\text { For frinda šn spur de ro } \\
\text { Whirdi an skildè meun } \\
\text { Our glas buryon burtaga. }\end{array}$ & $\begin{array}{l}\text { 1. } \\
\text { Da vara Iarlin o Orkneyar } \\
\text { For frinda š̌n spurde ro, } \\
\text { Whirdì an skildè meun } \\
\text { Or vannaro eidnar fuo- } \\
\text { Or glasburyon burtaga }\end{array}$ & $\begin{array}{l}1 . \\
\text { Dað var jarlin 'tá } \\
\text { Orkneyar } \\
\text { Fyr frænda sín spurdi ráo } \\
\text { Hvorti hann skuldi } \\
\text { meyen } \\
\text { Ó vandaráo hennar fá } \\
\text { (Ór glasborgin burttaga) }\end{array}$ \\
\hline $\begin{array}{l}2 . \\
\text { Or vanna ro eidnar fuo } \\
\text { Tega du meun our glas } \\
\text { buryon } \\
\text { Kere friendè min yamna } \\
\text { men } \\
\text { Eso vrildan stiendi gede } \\
\text { min vara to din. }\end{array}$ & $\begin{array}{l}2 . \\
\text { “Tega du meun our } \\
\text { glasburyon, } \\
\text { Kere friendè min, } \\
\text { Yamna meun eso vrildan } \\
\text { stiendu, } \\
\text { Gede min vara to din.” }\end{array}$ & $\begin{array}{l}2 . \\
\text { Tegur dú meyn ór } \\
\text { glasborgin } \\
\text { Kæri frændi mín } \\
\text { Jamnan me'n hesor } \\
\text { verilden stendur } \\
\text { Gedið mun varða til din. }\end{array}$ \\
\hline $\begin{array}{l}3 . \\
\text { Yom keimir cullingin } \\
\text { Fro liene burt } \\
\text { Asta Vaar hon fruen } \\
\text { Hildina } \\
\text { Hemi stu mer stien. }\end{array}$ & $\begin{array}{l}3 . \\
\text { Yom keimir eullingin } \\
\text { From liene; } \\
\text { Burt asta vaar hon fruen } \\
\text { Hildina, } \\
\text { Hemi stu-mer stien. }\end{array}$ & $\begin{array}{l}3 . \\
\text { Eðlingin kemur av leiðing } \\
\text { heim } \\
\text { Burtu stað var hon frún } \\
\text { Hildina } \\
\text { Eyðin stóð meyarstein }\end{array}$ \\
\hline $\begin{array}{l}4 . \\
\text { Whar an yaar elonden } \\
\text { Ita kan sadnast wo } \\
\text { An scal vara kundè } \\
\text { Wo osta tre sin reithin } \\
\text { ridna dar fro }\end{array}$ & $\begin{array}{l}4 . \\
\text { "Whar an yaar e londen } \\
\text { Ita kan sadnast wo, } \\
\text { An scal vara heindè wo } \\
\text { osta tre, } \\
\text { Sin reithin ridna darfro." }\end{array}$ & $\begin{array}{l}4 . \\
\text { Hvar hann jar í londom } \\
\text { Hetta kann sannast á } \\
\text { Hann skal varơa heingdur } \\
\text { á hásta tré } \\
\text { Sem rédin renna ífrá }\end{array}$ \\
\hline
\end{tabular}




\begin{tabular}{|c|c|c|}
\hline $\begin{array}{l}5 . \\
\text { Kemi to Orkneyar Jarlin } \\
\text { Vilda mien sante Maunis } \\
\text { I Orknian u bian sian } \\
\text { I lian far diar. }\end{array}$ & $\begin{array}{l}5 . \\
\text { "Kemi to Orkneyar Iarlin, } \\
\text { Sante Maunus vilda mien, } \\
\text { I Orknian u bian sian, } \\
\text { I lian far di an." }\end{array}$ & $\begin{array}{l}6 . \\
\text { Hann gevur drottningin } \\
\text { Kinnpustur undir kinn } \\
\text { Fyr sannu fóru tárir } \\
\text { Á hennar hvitrani kinn }\end{array}$ \\
\hline $\begin{array}{l}6 . \\
\text { An gevè Drotnign kedn } \\
\text { puster } \\
\text { On de kin firsane furu } \\
\text { Tworare wo eder } \\
\text { Whitranè kidn. }\end{array}$ & $\begin{array}{l}6 . \\
\text { An gevè Drotnign } \\
\text { Kednpuster onde kin; } \\
\text { Fir sane furu tworone } \\
\text { Wo edner whitrane kidn. }\end{array}$ & $\begin{array}{l}5 . \\
\text { Kemur til Orkneyar jarlin } \\
\text { — sante Mognus vil dað } \\
\text { mein- } \\
\text { í Orkneyom ogh býr hann } \\
\text { sí̉an } \\
\text { Í leiðang far dú enn'. }\end{array}$ \\
\hline $\begin{array}{l}7 . \\
\text { In kimerin Jarlin } \\
\text { U klapasse Hildina } \\
\text { On de kidn quirto } \\
\text { Vult doch, fiegan vara } \\
\text { moch or fly din. }\end{array}$ & $\begin{array}{l}7 . \\
\text { In kimer in Iarlin } \\
\text { U klapa se Hildina onde } \\
\text { kidn; } \\
\text { "Quirto vult doch fiegan } \\
\text { vara } \\
\text { Moch or fy din?" }\end{array}$ & $\begin{array}{l}7 . \\
\text { Inn kjemer Orknøy-jarlen } \\
\text { Og klappar si Hildina } \\
\text { unde kinn: } \\
\text { "Kvåre vilde du feigan } \\
\text { vera } \\
\text { Meg elder fa'er din? }\end{array}$ \\
\hline $\begin{array}{l}8 . \\
\text { Elde vilda fiegan vara } \\
\text { Fy min u alt sin } \\
\text { Ans namnu wo } \\
\text { So minyach u ere min } \\
\text { heve Orkneyar kingè ro. }\end{array}$ & $\begin{array}{l}8 . \\
\text { "Elde vild-a fiegan vara } \\
\text { Fy min u alt sin ans } \\
\text { namn u wo; } \\
\text { So min yach u ere min } \\
\text { heve } \\
\text { Orkneyar lingè ro. }\end{array}$ & $\begin{array}{l}8 . \\
\text { "Helder vilde eg feigan } \\
\text { vera } \\
\text { Får min og alt han å- } \\
\text { So skal eg og herren min } \\
\text { Yve Orknøyar lengje rå." }\end{array}$ \\
\hline $\begin{array}{l}9 . \\
\text { Nu di skall taga dor } \\
\text { yochwo } \\
\text { And u ria dor to } \\
\text { strandane nir } \\
\text { U yilsa fy minu avon } \\
\text { Blit an ear ne cumi i dora } \\
\text { band. }\end{array}$ & $\begin{array}{l}9 . \\
\text { Nu di skall taga dor yoch } \\
\text { wo and } \\
\text { U ria dor nir to strand, } \\
\text { U yilsa fy minu avon blit; } \\
\text { An earni cumi i dora } \\
\text { band." }\end{array}$ & $\begin{array}{l}9 . \\
\text { "Nú Dið skal taga Dor } \\
\text { jog á hand } \\
\text { Ogh ríða Dor ni'r til } \\
\text { strand } \\
\text { Ogh heilsa faðir mínom } \\
\text { avarblítt } \\
\text { Han gerni komi á Dora } \\
\text { band }\end{array}$ \\
\hline
\end{tabular}




\begin{tabular}{|c|c|c|}
\hline $\begin{array}{l}10 . \\
\text { Nu Swaran Konign } \\
\text { So mege gak honon i } \\
\text { muthi } \\
\text { Whath ear di ho gane } \\
\text { mier } \\
\text { I daute buthe. }\end{array}$ & $\begin{array}{l}10 . \\
\text { Nu swara an Konign } \\
\text { — so mege gak honon i } \\
\text { muthi-: } \\
\text { "Whath ear di ho gave } \\
\text { mier } \\
\text { I daute-buthe?" }\end{array}$ & $\begin{array}{l}10 . \\
\text { Nú svarað 'om konungin } \\
\text { —-so migið gakk honom í } \\
\text { móti- } \\
\text { Hvad eigir Dé að geva } \\
\text { Mér í dótturbóti? }\end{array}$ \\
\hline $\begin{array}{l}11 . \\
\text { Trettì merkè vath ru } \\
\text { godle } \\
\text { Da skall yach ger yo } \\
\text { U all de vara sonna less } \\
\text { So linge sin yach liva mo. }\end{array}$ & $\begin{array}{l}11 . \\
\text { "Trettì merkè vath ru } \\
\text { godle, } \\
\text { Da skall yach ger yo } \\
\text { U allde vara sonnaless, } \\
\text { So linge sin yach liva } \\
\text { mo." }\end{array}$ & $\begin{array}{l}11 . \\
\text { Trettí merkur ved reuðu } \\
\text { golli } \\
\text { Dað skal jag dér ljá } \\
\text { Ogh aldri að vara } \\
\text { sonolous } \\
\text { So leingi sem jag liva má }\end{array}$ \\
\hline \multirow[t]{2}{*}{$\begin{array}{l}12 . \\
\text { Nu linge stug an konign } \\
\text { U linge wo a swo } \\
\text { Wordig vaar dogh mugè } \\
\text { sonè } \\
\text { Yacha skier fare moga so } \\
\text { minde yach angan u frien } \\
\text { Rost wath comman mier } \\
\text { to landa. }\end{array}$} & $\begin{array}{l}12 . \\
\text { Nu linge stug an Konign, } \\
\text { U linge wo an swo: } \\
\text { "Wordig vaar dogh mugè } \\
\text { sonè; } \\
\text { Yach askier fare moga so. }\end{array}$ & $\begin{array}{l}12 . \\
\text { Nú leingi stóð han } \\
\text { konungin } \\
\text { Ogh leingi á han sá: } \\
\text { Verdig jar dog (mugi) } \\
\text { sonar } \\
\text { Jag askir fyri mág að sjá. }\end{array}$ \\
\hline & $\begin{array}{l}\text { 12b. } \\
\text { "So minde yach angan } \\
\text { ufrien rost, } \\
\text { Wath com an mier to } \\
\text { landa." }\end{array}$ & $\begin{array}{l}12 \mathrm{~b} . \\
\text { So mundi jag engan úfrín } \\
\text { ráost } \\
\text { Hoád komi han mér til } \\
\text { landa }\end{array}$ \\
\hline $\begin{array}{l}13 . \\
\text { Nu swara Hiluge } \\
\text { Hera geve honon scam } \\
\text { Taga di gild firre Hildina } \\
\text { Sin yach skall liga dor } \\
\text { fram. }\end{array}$ & $\begin{array}{l}13 . \\
\text { Nu swara Hiluge } \\
\text { — hera geve honom } \\
\text { scam-: } \\
\text { "Taga di gild firre Hildina } \\
\text { Sin yach skall lega dor } \\
\text { fram: }\end{array}$ & $\begin{array}{l}13 . \\
\text { Nú svarað Illugi } \\
\text { - Herra gev' onom } \\
\text { skamm! } \\
\text { Tagið Dé geld fyri } \\
\text { Hildina } \\
\text { Sem jag vil legga Dor } \\
\text { fram }\end{array}$ \\
\hline
\end{tabular}




\begin{tabular}{|c|c|c|}
\hline $\begin{array}{l}14 . \\
\text { Estin whaar u feur fetign } \\
\text { Agonga kadn i sluge } \\
\text { Feur fetign sin gonga } \\
\text { Kadn i pluge. }\end{array}$ & $\begin{array}{l}14 . \\
\text { Estin whaar u feur-fetign } \\
\text { A gonga kadn i sluge,-- } \\
\text { Estin whaar u feur-fetign } \\
\text { Sin gonga kadn i pluge." }\end{array}$ & $\begin{array}{l}14 . \\
\text { Hestin hvar og } \\
\text { ferfettingin } \\
\text { Að ganga kann í slóði } \\
\text {-----ferfettingin } \\
\text { sem ganga kann í plógi }\end{array}$ \\
\hline $\begin{array}{l}15 . \\
\text { Nu stienderin Jarlin. } \\
\text { U linge wo an wo } \\
\text { Dese mo eke Orknear } \\
\text { So linge san yach lava } \\
\text { mo. }\end{array}$ & $\begin{array}{l}15 . \\
\text { Nu stiender in Iarlin } \\
\text { U linge wo an swo: } \\
\text { "Dese mo eki Orknear, } \\
\text { So linge san yach lava } \\
\text { mo."- }\end{array}$ & $\begin{array}{l}15 . \\
\text { Nú stendur han Jarlin } \\
\text { Ogh leingi á han sá: } \\
\text { "Dessi má ekki Orkneyar } \\
\text { So leingi sem jag liva } \\
\text { má." }\end{array}$ \\
\hline $\begin{array}{l}16 . \\
\text { Nu eke tegaran san } \\
\text { Sot Koningn fyrin din } \\
\text { U alt yach an Hilhugin } \\
\text { Widn ugare din arar. }\end{array}$ & $\begin{array}{l}16 . \\
\text { "Nu eke tegar an san sot, } \\
\text { Koningn fyrin din; } \\
\text { U alt yach an Hilhugin } \\
\text { U garedin arar widn." }\end{array}$ & $\begin{array}{l}16 . \\
\text { Nú ekki tegur han } \\
\text { samsátt } \\
\text { Konungin faðirin din } \\
\text { Og helt jag han Illugin } \\
\text { Á gerðin aðrar vinna }\end{array}$ \\
\hline $\begin{array}{l}17 . \\
\text { Nu swarar an frauna } \\
\text { Hildina } \\
\text { U dem san idne i fro } \\
\text { Di slo dor a bardagana } \\
\text { Dar comme ov sin mo. }\end{array}$ & $\begin{array}{l}17 . \\
\text { Nu swarar an frauna } \\
\text { Hildina, } \\
\text { U dern san iden i fro: } \\
\text { "Di slo a bardagana, } \\
\text { Dar comme ov sin mo!" }\end{array}$ & $\begin{array}{l}17 . \\
\text { Nú svarar 'om frúen } \\
\text { Hildina } \\
\text { Í deim sama sinni frá: } \\
\text { "Dé sláiơ dor í } \\
\text { bardaganom } \\
\text { Dar komi áv sem má”. }\end{array}$ \\
\hline $\begin{array}{l}18 . \\
\text { Nu Jarlin an genger } \\
\text { I vadlin fram } \\
\text { U kadnar sina mien } \\
\text { Geven skeger i Orkneyan. }\end{array}$ & $\begin{array}{l}18 . \\
\text { Nu Iarlin an genger i } \\
\text { vadlin fram } \\
\text { U kadnar sìna mien, } \\
\text { Gever skeger i Orkneyan }\end{array}$ & $\begin{array}{l}18 . \\
\text { Nú jarlin han gangur á } \\
\text { vallin } \\
\text { Fram ogh kannar sína } \\
\text { menn: } \\
\text { Gævi skeggir í Orkneyum }\end{array}$ \\
\hline $\begin{array}{l}19 . \\
\text { Han u cummin } \\
\text { In u vod lerdin } \\
\text { Fronde fans lever } \\
\text { Vel burne mun. }\end{array}$ & $\begin{array}{l}19 . \\
\text { "Han u cummin } \\
\text { In u vodler din; } \\
\text { Frinde hans lever } \\
\text { Velburne mien." }\end{array}$ & $\begin{array}{l}19 . \\
\text { "Han er komin (við } \\
\text { úfriði) } \\
\text { Inn á vollin din; } \\
\text { Frændi f(aðir din) s leybir } \\
\text { Velborni menn." }\end{array}$ \\
\hline
\end{tabular}




\begin{tabular}{|c|c|c|}
\hline $\begin{array}{l}20 . \\
\text { Nu fruna Hildina } \\
\text { On genger i vadlin fram } \\
\text { Fy di yera da ov man dum } \\
\text { Dora di spidlaiki mire } \\
\text { man. }\end{array}$ & $\begin{array}{l}20 . \\
\text { Nu fruna Hildina, } \\
\text { On genger i vadlin fram: } \\
\text { "Fy di yera da ov } \\
\text { mandum dora, } \\
\text { Di spidla iki mira man." }\end{array}$ & $\begin{array}{l}20 . \\
\text { Nú frúen Hildina } \\
\text { Hon gengur í vollin fram } \\
\text { "Faðir, Dið gerið dað av } \\
\text { manndón Dora: } \\
\text { Dið spillið ekki meiri } \\
\text { mann." }\end{array}$ \\
\hline $\begin{array}{l}21 . \\
\text { Nu sware an Hiluge } \\
\text { Crego gevan a scam } \\
\text { Gayer an Jarlin frinde } \\
\text { Din an u fadlin in. }\end{array}$ & $\begin{array}{l}21 . \\
\text { Nu sware an Hiluge } \\
\text { - erego gev ana scam-: } \\
\text { "Yayer an Iarlin frinde din } \\
\text { An u fadlin in." }\end{array}$ & $\begin{array}{l}21 . \\
\text { Nú svarar hann Illugi } \\
\text { - Herreguð gevi honom } \\
\text { skamm- } \\
\text { "Heghar han Jarlin frændi } \\
\text { din } \\
\text { Han er fallin han." }\end{array}$ \\
\hline $\begin{array}{l}22 . \\
\text { Nu fac an Jarlin dahuge } \\
\text { Dar min de an engine gro } \\
\text { An east ans huge ei } \\
\text { Fong ednar u vaxhedne } \\
\text { more neo. }\end{array}$ & $\begin{array}{l}22 . \\
\mathrm{Nu} \text { fac an Iarlin dahuge } \\
\text { —dar minde an engin } \\
\text { gro-. } \\
\text { An cast ans huge ei fong } \\
\text { ednar, } \\
\text { U vaks hedne mere meo. }\end{array}$ & $\begin{array}{l}22 . \\
\text { Nú fakk 'an jarlin da } \\
\text { høggið } \\
\text { Dar mundi han eingin } \\
\text { grjó } \\
\text { Han kastað hans huguð í } \\
\text { fang hennar } \\
\text { Ogh vaks henni meiri } \\
\text { mjó. }\end{array}$ \\
\hline $\begin{array}{l}23 . \\
\text { Di lava mir gugna } \\
\text { Yift bal yagh fur o lande } \\
\text { Gipt mir nu fruan } \\
\text { Hildina } \\
\text { Vath godle u fasta bande. }\end{array}$ & $\begin{array}{l}23 . \\
\text { "Di lava mir yugna, } \\
\text { Yift bal yagh fur o landi; } \\
\text { Gipt mir un fruan } \\
\text { Hildina } \\
\text { Vath godle u fasta } \\
\text { bande." }\end{array}$ & $\begin{array}{l}23 . \\
\text { "Dé lovað mér hjónagift } \\
\text { Bel jag fór áv landi } \\
\text { Gipt mér nú frúen } \\
\text { Hildina } \\
\text { Ved golli ogh fastabandi." }\end{array}$ \\
\hline $\begin{array}{l}24 . \\
\text { Nu bill on heve da yals } \\
\text { Guadnè borè u da kadn } \\
\text { Sina kloyn a bera do skall } \\
\text { Fon fruna Hildina verka } \\
\text { wo sino chelsina villya. }\end{array}$ & $\begin{array}{l}24 . \\
\text { "Nu billon heve day alty } \\
\text { uadn è borè, } \\
\text { U da kadn sina kloyna } \\
\text { bera; } \\
\text { Do skall hon fruna } \\
\text { Hildina }\end{array}$ & $\begin{array}{l}24 . \\
\text { "Nú bel han hevir dað } \\
\text { jarlsbarn borið } \\
\text { Ogh dað kann sín kláðin } \\
\text { bera } \\
\text { Dá skal hon frúen } \\
\text { Hildina }\end{array}$ \\
\hline
\end{tabular}




\begin{tabular}{|c|c|c|}
\hline & $\begin{array}{l}\text { Verka wo sino chelsina } \\
\text { villya." }\end{array}$ & Ad sjalvs sína vilja gera.” \\
\hline $\begin{array}{l}25 . \\
\text { Hildina liger wo chaldona } \\
\text { U o dukrar u grothè } \\
\text { Min du buga till } \\
\text { bridlevsin } \\
\text { Bonlother u duka dogha. }\end{array}$ & $\begin{array}{l}25 . \\
\text { Hildina liger wo chaldona } \\
\text { Wo dukrar u grothè; } \\
\text { Min du buga till } \\
\text { bridlevsin, } \\
\text { Hon lothir u duka dogha. }\end{array}$ & $\begin{array}{l}25 . \\
\text { Hildina liggur á } \\
\text { tjaldenom } \\
\text { Eughað druknar í grádi } \\
\text { Me’n dei búga til } \\
\text { brulleubsins } \\
\text { Í drekka dágha hon ládur. }\end{array}$ \\
\hline $\begin{array}{l}26 . \\
\text { Nu Hildina on askar } \\
\text { feyrin } \\
\text { Sien di gava mier livè } \\
\text { Ou skinka vin } \\
\text { Ou guida vin. }\end{array}$ & $\begin{array}{l}26 . \\
\text { Nu Hildina on askar } \\
\text { Feyrin sien: } \\
\text { "Di gava mier live ou } \\
\text { skinka vin, } \\
\text { Ou guida vin." }\end{array}$ & $\begin{array}{l}26 . \\
\text { —-Nú---Hildina } \\
\text {-Askar faðirin sin } \\
\text {-Dið gevið mér leyvi } \\
\text { Að skeinka ogh gýda vín. }\end{array}$ \\
\hline $\begin{array}{l}27 . \\
\text { Duska skinka vin, u guida } \\
\text { vin } \\
\text { Tinka dogh eke wo } \\
\text { Jarlin an gougha here din. }\end{array}$ & $\begin{array}{l}27 . \\
\text { "Du ska skinka vin } \\
\text { U guida vin; } \\
\text { Tinka dagh eke wo Iarlin, } \\
\text { An gougha here din." }\end{array}$ & $\begin{array}{l}27 . \\
\text { "Dú skal--- } \\
\text { —-Skeinka ogh gýda vín; } \\
\text { Teink dog ekki á jarlin } \\
\text { Enn góða herri din." }\end{array}$ \\
\hline $\begin{array}{l}28 . \\
\text { Watha skilde tinka } \\
\text { Wo Jarlin gouga herè min } \\
\text { Hien minde yagh inga } \\
\text { forlskona } \\
\text { Bera fare kera fyrin min. }\end{array}$ & $\begin{array}{l}28 . \\
\text { "Wath a skilde tinka wo } \\
\text { Iarlin } \\
\text { An gouga herè min, } \\
\text { Hien mindi yagh inga } \\
\text { forlskona bera } \\
\text { Fare kera fyrin min." }\end{array}$ & $\begin{array}{l}28 . \\
\text { "Hóad jag skuldi teinka } \\
\text { Á jarlin góða herri min } \\
\text { Hén mundi jag einga } \\
\text { fárskonna bera } \\
\text { Fyri kæra faðir min.” }\end{array}$ \\
\hline $\begin{array}{l}29 . \\
\text { Da gerde on fruna } \\
\text { Hildina } \\
\text { On bar se mien ot } \\
\text { On soverin fest, } \\
\text { Fysin u quarsin sat. }\end{array}$ & $\begin{array}{l}29 . \\
\text { Da gerde on fruna } \\
\text { Hildina, } \\
\text { On bar se mien ot; } \\
\text { On sover in fest fysin, } \\
\text { Fysin u quar sin sat. }\end{array}$ & $\begin{array}{l}29 . \\
\text { Dað gerdi hon frúen } \\
\text { Hildina } \\
\text { Hon bar sé méðin ád } \\
\text { Hon sávir inn fyst faðir } \\
\text { sin } \\
\text { Ogh hvar sem — sad. }\end{array}$ \\
\hline $\begin{array}{l}30 . \\
\text { Da gerde un fruna } \\
\text { Hildina }\end{array}$ & $\begin{array}{l}30 . \\
\text { Da gerde un fruna } \\
\text { Hildina, }\end{array}$ & $\begin{array}{l}30 . \\
\text { Dað gerdi hon frúen } \\
\text { Hildina }\end{array}$ \\
\hline
\end{tabular}




\begin{tabular}{|c|c|c|}
\hline $\begin{array}{l}\text { On bard im ur } \\
\text { Hadlin burt sien on } \\
\text { laghdè } \\
\text { Gloug I otsta jatha port. }\end{array}$ & $\begin{array}{l}\text { On bar dim ur hadlin } \\
\text { burt; } \\
\text { Sien on laghdè gloug } \\
\text { I otsta jath a port. }\end{array}$ & $\begin{array}{l}\text { Hon bar deim ór hallin } \\
\text { burt } \\
\text { Síðan hon lagdi } \\
\text { glóðhough } \\
\text { Í otsta gadaport. }\end{array}$ \\
\hline $\begin{array}{l}31 . \\
\text { Nu iki visti an Hiluge } \\
\text { Ike ov till do } \\
\text { Eldin var commin i lut } \\
\text { U stor u silkè sark ans } \\
\text { smo. }\end{array}$ & $\begin{array}{l}31 . \\
\text { Nu iki visti an Hiluge } \\
\text { Ike ov till do } \\
\text { Eldin var commin i } \\
\text { lutustor } \\
\text { U silkisark ans smo. }\end{array}$ & $\begin{array}{l}31 . \\
\text { Nú ekki visti han Illugi } \\
\text { Ekki áv til dá } \\
\text { Eldin var komin í } \\
\text { lopthúsdor } \\
\text { Ogh silkiserk hans smá. }\end{array}$ \\
\hline $\begin{array}{l}32 . \\
\text { Nu leveren fram } \\
\text { Hiluge du kereda } \\
\text { Fraun Hildina du } \\
\text { Gevemir live u gre }\end{array}$ & $\begin{array}{l}32 . \\
\text { Nu lever en fram Hiluge } \\
\text { "Du keresta fraun } \\
\text { Hildina, } \\
\text { Du geve mir live u gre." }\end{array}$ & $\begin{array}{l}32 . \\
\text { Nú leybur fram han Illugi } \\
\text { "Dú kæri dað, frúen } \\
\text { Hildina, } \\
\text { Dú gevi mér lív ogh } \\
\text { grið." }\end{array}$ \\
\hline $\begin{array}{l}33 . \\
\text { So mege u gouga gre } \\
\text { Skall dogh swo } \\
\text { Skall lathì min heran } \\
\text { I bardagana fwo. } \\
\end{array}$ & $\begin{array}{l}33 . \\
\text { "So mege u gouga gre } \\
\text { Skall dogh swo, } \\
\text { Sin shall lathi min heran } \\
\text { I bardagana fwo. }\end{array}$ & $\begin{array}{l}33 . \\
\text { "So migið ogh góða } \\
\text { Grið skalt dog s(j)á } \\
\text {---lad mín herran } \\
\text { í bardagan fá." }\end{array}$ \\
\hline $\begin{array}{l}34 . \\
\text { Du tuchtada lide undocht } \\
\text { yach } \\
\text { Swo et sa ans bugin bleo } \\
\text { Dogh casta ans huge } \\
\text { I mit fung u vexemir mise } \\
\text { meo. }\end{array}$ & $\begin{array}{l}34 . \\
\text { Du tuchta da lide } \\
\text { undocht yach } \\
\text { Swo etsa ans bugin bleo; } \\
\text { Dogh casta ans huge i } \\
\text { mit fung, } \\
\text { U vexe mir mire meo." }\end{array}$ & $\begin{array}{l}34 . \\
\text { "Dú tókti dað lídið um } \\
\text { dótt jag } \\
\text { Sá hetsa hans búgin bljó; } \\
\text { Dog kastað hans huguð í } \\
\text { mitt fang } \\
\text { Ogh vaks mér meiri mjó." }\end{array}$ \\
\hline $\begin{array}{l}35 . \\
\text { Nu tachtè on heve } \\
\text { fwelsko } \\
\text { Ans bo vad mild u stien } \\
\text { Dogh skall aidè misè } \\
\text { Koningnsens } \\
\text { Vadna vilda mien. }\end{array}$ & $\begin{array}{l}35 . \\
\text { Nu tachtè on heve } \\
\text { fwelsko ans } \\
\text { Bo vad mild u stien. } \\
\text { "Dogh skall aldè mirè } \\
\text { Koningnsens } \\
\text { Vadne vilda mien." }\end{array}$ & $\begin{array}{l}35 . \\
\text { Nú takti hon yvi følska } \\
\text { hans } \\
\text { Bá ved møld og stein: } \\
\text { "Dog skal aldri meir } \\
\text { konungsins } \\
\text { Barni valda mein." }\end{array}$ \\
\hline
\end{tabular}




\section{The Hildina Ballad: Attempts at translation}

As mentioned before, the first scholar who tried to make some sense of the Hildina Ballad was Peter Andreas Munch in Geographiske og historiske notitser om Orknoërne og Hetland (1839), but he only managed to render about half of the ballad into Old Norse and Danish. It was not until Hægstad's study in 1900 that a more or less reliable version of the Hildina Ballad became available. As a matter of fact, Hægstad's version has been the main reference for all the translations of the ballad into a few modern languanges. So far, there is one German translation by J. E. Poestion (1914), two Norwegian (nynorsk) translations by Marius Hægstad himself (1901) and Eigil Lehmann (1984), and three renderings into English by W. G. Collingwood (1908), Norah Kershaw (1921), ${ }^{19}$ and Graeme Davis (2007) ${ }^{20}$ In contrast to the German and Norwegian translations, the English versions have been published more than once. ${ }^{21}$

The three tables below offer a comparison of the ballad's translations, following a chronological order.

\footnotetext{
${ }^{19}$ However, Kershaw only translated the first twelve stanzas of the ballad.

${ }^{20}$ Davis's translation can also be considered an attempt at creative reconstruction or rewriting, as he offers quite a free version of the ballad.

${ }^{21}$ Apart from more recent online editions, Collingwood's translation has also been published by Graham \& Graham (1998), whereas Kershaw's rendering was published as well by Leach (1946) and Davis (2007). Davis's own version was also published by the newspaper The Orcadian on January 3, 2008. Oddly enough, Syndergaard (1995) only mentions Leach's English version, which, as mentioned above, is actually Kershaw's.
} 
Table 2. Hildina Ballad: attempts at translation (I)

\begin{tabular}{|c|c|c|}
\hline $\begin{array}{l}\text { SOPHUS BUGGE } \\
(\text { c. 1897) } \\
\end{array}$ & $\begin{array}{c}\text { MARIUS HÆGSTAD } \\
(1901) \\
\end{array}$ & $\begin{array}{c}\text { W. G. COLLINGWOOD } \\
(1908)\end{array}$ \\
\hline $\begin{array}{l}1 . \\
\text { pað }[\text { sic] var jarlinn af } \\
\text { Orkneyjum } \\
\text { Af frænda sína spurði } \\
\text { ráð: } \\
\text { Hvert hann skyldi } \\
\text { meyna or glasborginni } \\
\text { burttaka } \\
\text { Eða vinaráð fá. }\end{array}$ & $\begin{array}{l}1 . \\
\text { Det var jarlen or } \\
\text { Orknøyom, } \\
\text { Han spurde sin frende } \\
\text { um raad, } \\
\text { Um han skulde den møyi } \\
\text { Or vanden hennar faa, - } \\
\quad \text { Or glasborgi burt- } \\
\text { taka }\end{array}$ & $\begin{array}{l}1 . \\
\text { It was the Earl of Orkney } \\
\text { Of his friend has taken rede } \\
\text { Whereby to bring a maiden } \\
\text { Forth of her perilous need } \\
\text { - } \\
\text { From the broch of glass to } \\
\text { save her. }\end{array}$ \\
\hline $\begin{array}{l}2 . \\
\text { “Tekr pú meyna or } \\
\text { glasborginni, } \\
\text { Kæri frændi minn, } \\
\text { Jamnan meðan æ svo } \\
\text { veröldin stendr } \\
\text { Getit mun vera til pín.” }\end{array}$ & $\begin{array}{l}2 . \\
\text { "Teker du møyi or } \\
\text { glasborgi, } \\
\text { Kjære venen min, } \\
\text { So lenge som denne } \\
\text { verdi stender, } \\
\text { Skal spyrjast mannskapen } \\
\text { din." }\end{array}$ & $\begin{array}{l}2 . \\
\text { "Take ye the maid from the } \\
\text { broch of glass, } \\
\text { Dearest friend of mine, } \\
\text { And aye as long as the } \\
\text { world may stand } \\
\text { Shall be told this deed of } \\
\text { thine." }\end{array}$ \\
\hline $\begin{array}{l}3 . \\
\text { [Her] kemr øðlinginn } \\
\text { frá leiðinni [heim], } \\
\text { burt á stað var hon } \\
\text { frúin Hildina, } \\
\text { [tómr] stoð } \\
\text { meyarsteinn. }\end{array}$ & $\begin{array}{l}3 . \\
\text { Heim kjemer edlingen } \\
\text { Fraa leiding med sine } \\
\text { menn. } \\
\text { Burte og vekk var fru } \\
\text { Hildina; } \\
\text { Heime stykmôr stend. }\end{array}$ & $\begin{array}{l}3 . \\
\text { Homeward comes the noble } \\
\text { king } \\
\text { From the hosting as he } \\
\text { rides, } \\
\text { But gone is the lady } \\
\text { Hildina; } \\
\text { At home her step-dame } \\
\text { bides. }\end{array}$ \\
\hline $\begin{array}{l}4 . \\
\text { “Hvar hann er í } \\
\text { landinu, } \\
\text { Ef pat kann sannast á: } \\
\text { Hann skal verða hengdr } \\
\text { á hæsta tré } \\
\text { Sem rótinn rennr par } \\
\text { frá.” }\end{array}$ & $\begin{array}{l}4 . \\
\text { "Kvar han er I landi } \\
\text { Dette kann sannast paa, } \\
\text { Han skal verta hengd I } \\
\text { det høgste tre } \\
\text { Som rotom renner ifraa." }\end{array}$ & $\begin{array}{l}4 . \\
\text { "Whoever in all the land be } \\
\text { he } \\
\text { Is guilty of this thing, } \\
\text { He shall be hanged on the } \\
\text { highest tree } \\
\text { That forth of root may } \\
\text { spring!" }\end{array}$ \\
\hline
\end{tabular}




\begin{tabular}{|c|c|c|}
\hline $\begin{array}{l}5 . \\
\text { “Kemr til Orkneya [sic] } \\
\text { jarlinn, } \\
\text { —valda man, Sankti } \\
\text { Magn(u)s- } \\
\text { Í Orkneyjum pér bíðið } \\
\text { síð̇an [bana] } \\
\text { Í leiðangs-ferð í ár.” }\end{array}$ & $\begin{array}{l}5 . \\
\text { "Kjemer jarlen til } \\
\text { Orknøyar, } \\
\text { St. Magnus kann styra } \\
\text { det so: } \\
\text { Han vert der verande all } \\
\text { si tid; } \\
\text { Far difor etter han no." }\end{array}$ & $\begin{array}{l}5 . \\
\text { "If the earl be come to } \\
\text { Orkney, } \\
\text { St. Magnus will keep him } \\
\text { there, } \\
\text { For his home is aye in } \\
\text { Orkney; } \\
\text { Then forth with thy hosting } \\
\text { fare." }\end{array}$ \\
\hline $\begin{array}{l}6 . \\
\text { Hann gefr } \\
\text { dróttningunni } \\
\text { Kinnpúst under kinn; } \\
\text { Fyrsandi fóru tárir } \\
\text { Á hennar hvítrinni } \\
\text { kinn. }\end{array}$ & $\begin{array}{l}6 . \\
\text { Daa gav han dronningi } \\
\text { Ein kinnhest under kinn; } \\
\text { Med sanno rann det } \\
\text { taaror } \\
\text { Paa hennar kvitare kinn. }\end{array}$ & $\begin{array}{l}6 . \\
\text { Whereat he gave the queen } \\
\text { a clout } \\
\text { On the cheek in wrath and } \\
\text { spite, } \\
\text { And O but the tears went } \\
\text { coursing } \\
\text { Adown her cheek so white. }\end{array}$ \\
\hline $\begin{array}{l}7 . \\
\text { Inn kemr hann jarlinn } \\
\text { Ok klappar sær Hildina } \\
\text { undir kinn: } \\
\text { “Hvárt vilt pú feigan } \\
\text { vera } \\
\text { Mik eða föður [sic] } \\
\text { pinn?” }\end{array}$ & $\begin{array}{l}7 . \\
\text { Inn kjemer den jarlen, } \\
\text { Klappar Hildina under } \\
\text { kinn: } \\
\text { "Kven vil du no feig skal } \\
\text { vera, } \\
\text { Eg eller fa'er din?" }\end{array}$ & $\begin{array}{l}7 . \\
\text { In came the earl and } \\
\text { fondled } \\
\text { Hildina's cheek in glee: - } \\
\text { "Now whether of us are ye } \\
\text { fainer of- } \\
\text { Your father, or of me?" }\end{array}$ \\
\hline $\begin{array}{l}8 . \\
\text { "Heldr vilda’k feigan } \\
\text { vera föður }[\text { sic }] \text { minn, } \\
\text { Ok alt sem hans nafn á; } \\
\text { Svá mun ek ok, herra } \\
\text { minn, } \\
\text { Hava Orkneya lengi ráð. }\end{array}$ & $\begin{array}{l}8 . \\
\text { "Heller vilde eg fâr var } \\
\text { feig } \\
\text { Og alt som hans namn er } \\
\text { paa; } \\
\text { Daa skulde eg og min } \\
\text { hæve herre } \\
\text { Orknøyar lenge raa". } \\
\end{array}$ & $\begin{array}{l}8 . \\
\text { "I would sooner be fain of } \\
\text { my father } \\
\text { And of aught that he can } \\
\text { say, } \\
\text { So shall I and my lord have } \\
\text { Orkney } \\
\text { To rule for many a day. }\end{array}$ \\
\hline $\begin{array}{l}9 . \\
\text { Nú pér skal taka yðr } \\
\text { hauk á hönd, } \\
\text { Ok ríða yðr nior til } \\
\text { stranda; }\end{array}$ & $\begin{array}{l}9 . \\
\text { No skal du taka ein } \\
\text { gangar fram } \\
\text { Og rida deg ned til } \\
\text { strand, }\end{array}$ & $\begin{array}{l}9 . \\
\text { "Now shalt thou take thy } \\
\text { horse in hand } \\
\text { And down to the water } \\
\text { wend, }\end{array}$ \\
\hline
\end{tabular}




\begin{tabular}{|c|c|c|}
\hline $\begin{array}{l}\text { Ok heilsa föður mínum } \\
\text { afar-blítt } \\
\text { Hann er nýkominn í } \\
\text { yoru [1]andi. }\end{array}$ & $\begin{array}{l}\text { Og helsa fâr min ovende } \\
\text { blidt; } \\
\text { Maa henda de semjast } \\
\text { kann.” }\end{array}$ & $\begin{array}{l}\text { And greet my father fair and } \\
\text { blithe; } \\
\text { He will gladly be thy } \\
\text { friend." }\end{array}$ \\
\hline $\begin{array}{l}10 . \\
\text { Nú svarar hann } \\
\text { konungrinn, } \\
\text { Svo mikit gekk honum } \\
\text { í móti: } \\
\text { "Hvat eruð pit í hugi } \\
\text { Gefa mér í dóttur- } \\
\text { bótum? }\end{array}$ & $\begin{array}{l}10 . \\
\text { No svara konongen } \\
\text { — so mykje gjekk honom } \\
\text { imot- } \\
\text { "Kva hev du aa gjeva meg } \\
\text { I dotterbot?" }\end{array}$ & $\begin{array}{l}10 . \\
\text { Then said the king - for a } \\
\text { many } \\
\text { Came riding to meet him } \\
\text { there- } \\
\text { "What gift hast thou gotten } \\
\text { to give me } \\
\text { In fee for my daughter fair?" }\end{array}$ \\
\hline $\begin{array}{l}11 . \\
\text { "prjátíu merkr við } \\
\text { rauðugulli, } \\
\text { pat skal ek gera hjá, } \\
\text { Ok aldri [skaltu] vera } \\
\text { sonalauss, } \\
\text { Svá lengi sem ek lifa } \\
\text { má.” }\end{array}$ & $\begin{array}{l}11 . \\
\text { "Tretti merker I } \\
\text { raudegull, } \\
\text { Det skal du hjaa meg faa, } \\
\text { Og aldri vera sonelaus, } \\
\text { So lenge som eg liva } \\
\text { maa." }\end{array}$ & $\begin{array}{l}11 . \\
\text { Thirty marks of gold so red } \\
\text { Is the gift that I will give; } \\
\text { Forbye for a son ye never } \\
\text { shall lack } \\
\text { The while that I may live." }\end{array}$ \\
\hline $\begin{array}{l}\text { 12a. } \\
\text { Nú lengi stóð hann } \\
\text { konungrinn, } \\
\text { Ok lengi á hann sá: } \\
\text { "Verougr vart pú mági, } \\
\text { syni, } \\
\text { Ek á skarð fyri mága." }\end{array}$ & $\begin{array}{l}12 . \\
\text { No lenge stod den } \\
\text { konongen, } \\
\text { Og lenge paa honom } \\
\text { saag: } \\
\text { "Du er jamgod med } \\
\text { mange søner, } \\
\text { Eg ynskjer me semjast } \\
\text { maa. }\end{array}$ & $\begin{array}{l}12 . \\
\text { Now long stood the King } \\
\text { before him, } \\
\text { And long on the earl looked } \\
\text { he:- } \\
\text { "Well worth many a son art } \\
\text { thou! } \\
\text { I would that it so might be! }\end{array}$ \\
\hline $\begin{array}{l}\text { 12b. } \\
\text { "[Vilduð pér frúna } \\
\text { Hildina } \\
\text { Geva mér til handa] } \\
\text { Svá mundi [o]k engan } \\
\text { frændorrust } \\
\text { póat koma mér til } \\
\text { landa." }\end{array}$ & $\begin{array}{l}13 . \\
\text { [Og fer det som eg } \\
\text { ynskjer det, } \\
\text { At du gjeng meg til } \\
\text { hande,] } \\
\text { Daa skulde eg ingen uven } \\
\text { ræddast, } \\
\text { Um han kom meg til } \\
\text { lande." }\end{array}$ & $\begin{array}{l}\text { 13a. } \\
\text { [“When Orkney's earl and } \\
\text { Norway's king } \\
\text { In league together stand } \\
\text { So need I fear no foe soe'er } \\
\text { Might come within my } \\
\text { land."] }\end{array}$ \\
\hline
\end{tabular}




\begin{tabular}{|c|c|c|}
\hline $\begin{array}{l}13 . \\
\text { Nú svaraði Hillugi, } \\
\text { Herra [Guð] gefi } \\
\text { honum skamm: } \\
\text { "Takið pit gjöld fyri } \\
\text { Hildina } \\
\text { Sem ek skal leggja yðr } \\
\text { fram.” }\end{array}$ & $\begin{array}{l}14 . \\
\text { No svarar Hilluge } \\
\text { —Herre, gjev honom } \\
\text { skam-: } \\
\text { "Tak vederlag for Hildina } \\
\text { Som eg vil leggja fram: }\end{array}$ & $\begin{array}{l}\text { 13b. } \\
\text { Then up and spoke Illugi - } \\
\text { The Lord to him give } \\
\text { shame!- } \\
\text { "This fee shall ye take for } \\
\text { Hildina } \\
\text { As I shall set the same:- }\end{array}$ \\
\hline $\begin{array}{l}14 . \\
\text { Hestarnir verða } \\
\text { fjörutíu, } \\
\text { Er ganga kann í slóði, } \\
\text { [Hestarnir verða] } \\
\text { fjörutíu, } \\
\text { Sem ganga kann í } \\
\text { plógi.” }\end{array}$ & $\begin{array}{l}15 . \\
\text { Kvar ein hest og } \\
\text { firføting, } \\
\text { So før at ei horv han } \\
\text { drog,-- } \\
\text { Kvar ein hest og firføting } \\
\text { Som ganga kann for } \\
\text { plog.” }\end{array}$ & $\begin{array}{l}14 . \\
\text { "Every horse and four-foot } \\
\text { beast } \\
\text { That trails a load [in snow]; } \\
\text { Every horse and four-foot } \\
\text { beast } \\
\text { That in the plough can go." }\end{array}$ \\
\hline $\begin{array}{l}15 . \\
\text { Nú stendur [sic] hann } \\
\text { jarlinn, } \\
\text { Ok lengi á hann sá: } \\
\text { "pessi má ekki } \\
\text { Orkneyjar, } \\
\text { Svá lengi ek lifa má. }\end{array}$ & $\begin{array}{l}16 . \\
\text { No stender han, jarlen, } \\
\text { Og lenge paa honom } \\
\text { saag: } \\
\text { "Dette vinn ikkje } \\
\text { Orknøyar, } \\
\text { So lenge eg liva maa. }\end{array}$ & $\begin{array}{l}15 . \\
\text { Then stood the earl before } \\
\text { him } \\
\text { And a long look on him } \\
\text { cast: } \\
\text { "Never shall Orkney grant } \\
\text { that gift } \\
\text { The while my life may last!" }\end{array}$ \\
\hline $\begin{array}{l}16 . \\
\text { Nú ekki tekr hann } \\
\text { samsátt, } \\
\text { Konungrinn faðir pinn; } \\
\text { Ok helt ek hann } \\
\text { Hillugin } \\
\text { Vildi ok gerast herra } \\
\text { pinn." }\end{array}$ & $\begin{array}{l}17 . \\
\text { No tek han ikkje mot } \\
\text { semja god, } \\
\text { Konongen fa'er din. } \\
\text { Eg tenkte meg og at } \\
\text { Hilluge } \\
\text { Ber anna uti sitt sinn.” }\end{array}$ & $\begin{array}{l}16 . \\
\text { "Now never more his troth } \\
\text { and trust } \\
\text { Will the king thy father } \\
\text { yield; } \\
\text { And sore I doubt me Illugi } \\
\text { Would plough his } \\
\text { neighbour's field." }\end{array}$ \\
\hline $\begin{array}{l}17 . \\
\text { Nú svarar hon frúin } \\
\text { Hildina } \\
\text { Í pví sömu [s]inni ífrá: }\end{array}$ & $\begin{array}{l}18 . \\
\text { No svarar fru Hildina } \\
\text { Or døri si inne ifraa: }\end{array}$ & $\begin{array}{l}17 . \\
\text { And the lady Hildina } \\
\text { answered him, } \\
\text { As behind the door she sat: }\end{array}$ \\
\hline
\end{tabular}




\begin{tabular}{|c|c|c|}
\hline $\begin{array}{l}\text { "pit sláið̌ yðr í } \\
\text { bardagana, } \\
\text { par komi af sem má." }\end{array}$ & $\begin{array}{l}\text { "So fær de stridast med } \\
\text { odd og egg, } \\
\text { Det gange av som det } \\
\text { maa." }\end{array}$ & $\begin{array}{l}\text { "Then meet him in the } \\
\text { battle, } \\
\text { And come what will of } \\
\text { that!" }\end{array}$ \\
\hline $\begin{array}{l}18 . \\
\text { Nú jarlinn hann gengr í } \\
\text { völlinn fram, } \\
\text { Ok kannar sína menn: } \\
\text { "Göfgir skeggjar í } \\
\text { Orkneyjum, } \\
\text { [verjast viljum vér } \\
\text { enn].” }\end{array}$ & $\begin{array}{l}19 . \\
\text { No jarlen han gjeng paa } \\
\text { vollen fram } \\
\text { Og kannar sine menn, } \\
\text { Dei gjeve skjeggjar i } \\
\text { Orknøyom, } \\
\text { [velborne menn]. }\end{array}$ & $\begin{array}{l}18 . \\
\text { Forth goes the earl to the } \\
\text { field of war } \\
\text { And orders his array- } \\
\text { The peaceful Orkney- } \\
\text { beardies } \\
\text { [For the fearsome battle- } \\
\text { play] }\end{array}$ \\
\hline $\begin{array}{l}19 . \\
\text { "Hann er komin [med } \\
{[s i c] \text { ófriði] }} \\
\text { In }[s i c] \text { á völlinn pín; } \\
\text { Frændi [h]ans hleypir } \\
\text { Velbornir menn." }\end{array}$ & $\begin{array}{l}20 . \\
\text { "Kongen, han er komen; } \\
\text { Paa vollen din han stend. } \\
\text { Venen hans driv paa flugt } \\
\text { Dei velborne menn." }\end{array}$ & $\begin{array}{l}19 . \\
\text { "He is marching through } \\
\text { thy fields, lady, } \\
\text { [He has broken garth and } \\
\text { wall,] } \\
\text { And all his friends are } \\
\text { following } \\
\text { And thy noble folk they } \\
\text { fall!" }\end{array}$ \\
\hline $\begin{array}{l}20 . \\
\text { Nú frúin Hildina } \\
\text { Hon gengr í völlin } \\
\text { fram: } \\
\text { "Faðir, pit gerið pat af } \\
\text { manndómi yðar, } \\
\text { pit spill' ekki meira } \\
\text { manna." }\end{array}$ & $\begin{array}{l}21 . \\
\text { No fruva Hildina } \\
\text { Ho gjenger i vollen fram: } \\
\text { "Fâr, aa gjer no eit } \\
\text { manndomsverk, } \\
\text { Og spill ikkje fleire } \\
\text { mann!" }\end{array}$ & $\begin{array}{l}20 . \\
\text { Now lady Hildina hies her } \\
\text { Forth to the field of } \\
\text { strife:- } \\
\text { "Father, for manhood's sake } \\
\text { forebear, } \\
\text { And stay this waste of life!" }\end{array}$ \\
\hline $\begin{array}{l}21 . \\
\text { Nú svarar hann Hillugi, } \\
\text { [H]erra Gúo [sic] gefi } \\
\text { honom skam }[s i c] \text { : } \\
\text { "Pegar hann jarlinn } \\
\text { frændi pinn, } \\
\text { Hann er fallin [sic] } \\
\text { enn." }\end{array}$ & $\begin{array}{l}22 . \\
\text { No svarar han Hilluge } \\
\text {-Herre gud gjev honom } \\
\text { skam-: } \\
\text { "Ja, naar jarlen, venen } \\
\text { din, } \\
\text { Ogso er fallen, han." }\end{array}$ & $\begin{array}{l}21 . \\
\text { Then up and spoke Illugi - } \\
\text { The Lord God him } \\
\text { requite!- } \\
\text { "No sooner than the earl, } \\
\text { thy love, } \\
\text { Has fallen in the fight." }\end{array}$ \\
\hline
\end{tabular}




\begin{tabular}{|c|c|c|}
\hline $\begin{array}{l}22 . \\
\text { Nú fekk hann } \\
\text { jarlin[um] pat höggit, } \\
\text { par mundi hann enginn } \\
\text { grœða, } \\
\text { Hann kasti hans höfði í } \\
\text { fang hennar, } \\
\text { Ok vexti henni meiri } \\
\text { mœði. }\end{array}$ & $\begin{array}{l}23 . \\
\text { No fekk jarlen } \\
\text { daudehogg } \\
\text { —det saaret kunde ei } \\
\text { gro- } \\
\text { Han kasta hans hovud I } \\
\text { fanget hennar, } \\
\text { Daa voks det stort } \\
\text { hennar mod. }\end{array}$ & $\begin{array}{l}22 . \\
\text { Then gat the earl his death- } \\
\text { stroke- } \\
\text { No hand could heal him } \\
\text { more. } \\
\text { He cast his head into her } \\
\text { arms, } \\
\text { And O but her heart was } \\
\text { sore! }\end{array}$ \\
\hline $\begin{array}{l}23 . \\
\text { "pit lofaði mér góða } \\
\text { giftu, } \\
\text { Bili ek fór ór landi: } \\
\text { Gipt mér nú frúna } \\
\text { Hildina } \\
\text { Við gulli ok festar } \\
\text { bandi." }\end{array}$ & $\begin{array}{l}24 . \\
\text { "De lova meg gifta, } \\
\text { Um djerv eg fór or lande. } \\
\text { Gjev meg no fru Hildina } \\
\text { Med gull og festebande." }\end{array}$ & $\begin{array}{l}23 . \\
\text { "Grant me to be the } \\
\text { bridegroom, } \\
\text { So bold have I followed } \\
\text { thee; } \\
\text { To the lady Hildina wed me } \\
\text { now } \\
\text { With gold and festing-fee." }\end{array}$ \\
\hline $\begin{array}{l}24 . \\
\text { "Nú bili hon hefir pat } \\
\text { jarlsbarnit borit, } \\
\text { Ok pat kann sín klæðin } \\
\text { at bera, } \\
\text { pá skalt [h] on frúna } \\
\text { Hildina } \\
\text { Verka á sinum [sic] } \\
\text { sjálfssína vilja." }\end{array}$ & $\begin{array}{l}25 . \\
\text { "No bidlund have du til } \\
\text { barn er boret } \\
\text { Og det kann sine klæde } \\
\text { bera, } \\
\text { Daa skal fruva Hildina } \\
\text { Faa sjølvs sin vilje gjera." }\end{array}$ & $\begin{array}{l}24 . \\
\text { "Forbear thou then till the } \\
\text { bairn be born, } \\
\text { And fair in swaddling dight; } \\
\text { Then shall lady Hildina } \\
\text { order this } \\
\text { Even as she deemeth right." }\end{array}$ \\
\hline $\begin{array}{l}25 . \\
\text { Hildina liggr á tjaldinu, } \\
\text { Ok hon hjúfrar ok } \\
\text { grætr: } \\
\text { Meðan peir búa til } \\
\text { brullaupsins } \\
\text { Bæði daga ok dökkar } \\
\text { [n]ætr. }\end{array}$ & $\begin{array}{l}26 . \\
\text { Hildina ligger paa tjeldet, } \\
\text { Og augo dimme ho græt, } \\
\text { Men daa dei bur til } \\
\text { brudlaupet, } \\
\text { Ho daae I drykken læt. }\end{array}$ & $\begin{array}{l}25 . \\
\text { On tapestry fair Hildina lay, } \\
\text { Her eye was dim with dole; } \\
\text { But while they dressed the } \\
\text { bridal-feast } \\
\text { She brewed a drowsy bowl. }\end{array}$ \\
\hline $\begin{array}{l}26 . \\
\text { Nú [kemr hon] } \\
\text { Hildina, }\end{array}$ & $\begin{array}{l}27 . \\
\text { Ho Hildina ho beder } \\
\text { Fa'er sin; }\end{array}$ & $\begin{array}{l}26 . \\
\text { Then up and spoke Hildina, }\end{array}$ \\
\hline
\end{tabular}




\begin{tabular}{|c|c|c|}
\hline $\begin{array}{l}\text { Hon æskir föður }[s i c] \\
\text { sinn: } \\
\text { "Pér gefid [sic] mér leyfi } \\
\text { At skenkja [mjöð] ok } \\
\text { gjóta vín?” }\end{array}$ & $\begin{array}{l}\text { "Du gjeve meg løyve aa } \\
\text { skenkja vin, } \\
\text { Aa fylla i vin." }\end{array}$ & $\begin{array}{l}\text { And prayed her father dear: } \\
\text { - } \\
\text { thow grant me leave to fill } \\
\text { And pour the wine so } \\
\text { clear." }\end{array}$ \\
\hline $\begin{array}{l}27 . \\
\text { “pú skalt [hafa leyfi] } \\
\text { At skenkja [mjöð] ok } \\
\text { gjóta vín, } \\
\text { penk pú ekki á jarlinn } \\
\text { pann göfga herra pinn. }\end{array}$ & $\begin{array}{l}28 . \\
\text { "Du skal skenkja vin } \\
\text { Og fylla i vin; } \\
\text { Men tenk no ikkje paa } \\
\text { jarlen, } \\
\text { Den gode herren din." }\end{array}$ & $\begin{array}{l}27 . \\
\text { "And who but thou should } \\
\text { fill the cup, } \\
\text { And pour for us the wine? } \\
\text { But think no more upon } \\
\text { the earl, } \\
\text { That worthy lord of thine." }\end{array}$ \\
\hline $\begin{array}{l}28 . \\
\text { "Hvat skyld ek penkja á } \\
\text { jarlinn, } \\
\text { Göfga herra minn, } \\
\text { Heðan mundi ek engra } \\
\text { forlaganna bera } \\
\text { Fyri kæra föðurinn [sic] } \\
\text { minn.” }\end{array}$ & $\begin{array}{l}29 . \\
\text { "Um eg tenkte paa } \\
\text { jarlen, } \\
\text { Den gode herren min, } \\
\text { Eg vilde daa ingi svik- } \\
\text { kanna bera } \\
\text { Fram fyre fa'er min." }\end{array}$ & $\begin{array}{l}28 . \\
\text { "Upon the earl, my worthy } \\
\text { lord, } \\
\text { Though ever should I think, } \\
\text { Yet shall I bring my father } \\
\text { dear } \\
\text { No draught of ill to drink." }\end{array}$ \\
\hline $\begin{array}{l}29 . \\
\text { pat gerði hon, frúin } \\
\text { Hildina, } \\
\text { Hon bar svá mjöðinn } \\
\text { at; } \\
\text { Hon svæfir hann fast } \\
\text { föður [sic] sinn, } \\
\text { Ok hvern sem [inni] } \\
\text { sat. }\end{array}$ & $\begin{array}{l}30 . \\
\text { Det gjorde fru Hildina, } \\
\text { Ho fram den mjøden } \\
\text { bar; } \\
\text { Ho svæver so fast inn } \\
\text { fâren, } \\
\text { Fâren og alle som var. }\end{array}$ & $\begin{array}{l}29 . \\
\text { Thus wrought the lady } \\
\text { Hildina- } \\
\text { She bore the wine around, } \\
\text { And fast asleep her father } \\
\text { lay, } \\
\text { With his folk upon the } \\
\text { ground. }\end{array}$ \\
\hline $\begin{array}{l}30 . \\
\text { pat gerði hon frúin } \\
\text { Hildina, } \\
\text { Hon bar peim or } \\
\text { höllinni burt; } \\
\text { Siðan hon lagði } \\
\text { glœðurnar } \\
\text { I [sic] ýtsta gátt á port. }\end{array}$ & $\begin{array}{l}31 . \\
\text { Det gjorde Hildina, } \\
\text { Ho bar deim or halli } \\
\text { burt; } \\
\text { Sidan lagde ho eld og } \\
\text { glod } \\
\text { I ytste op I port. }\end{array}$ & $\begin{array}{l}30 . \\
\text { Thus wrought she: - her } \\
\text { father and all his folk } \\
\text { Forth of the hall she bore } \\
\text { Thereafter fire she laid alow } \\
\text { To the outermost gate of } \\
\text { the door. }\end{array}$ \\
\hline
\end{tabular}




\begin{tabular}{|c|c|c|}
\hline $\begin{array}{l}31 . \\
\text { Nú ekki vissi hann } \\
\text { Hillugi } \\
\text { Ekki af til pá: } \\
\text { Eldrinn var kominn í } \\
\text { loft ok stóð } \\
\text { Á silkiserkinn smá. }\end{array}$ & $\begin{array}{l}32 . \\
\text { No ikkje visste han } \\
\text { Hilluge } \\
\text { Noko av til daa } \\
\text { Elden var komen i } \\
\text { lofthusdør } \\
\text { Og silkeserken hans } \\
\text { smaa. }\end{array}$ & $\begin{array}{l}31 . \\
\text { And nothing Illugi heeded, } \\
\text { And nought he knew at all, } \\
\text { Till the fire came in at the } \\
\text { loft-house door, } \\
\text { On his silken sark so small. }\end{array}$ \\
\hline $\begin{array}{l}32 . \\
\text { Nú hleypr hann fram } \\
\text { Hillugi } \\
\text { [Hann vissi sér engi } \\
\text { lið]: } \\
\text { "pú geri pat, frúin } \\
\text { Hildina, } \\
\text { pú gefi mér líf ok grið." }\end{array}$ & $\begin{array}{l}33 . \\
\text { No springer han Hilluge } \\
\text { fram, } \\
\text { [stod uti borge-led]: } \\
\text { "Aa, kjæraste du fru } \\
\text { Hildina, } \\
\text { Du gjeve meg liv og } \\
\text { grid!" }\end{array}$ & $\begin{array}{l}32 . \\
\text { Then up Illugi started, } \\
\text { [And the flame around was } \\
\text { rife]: } \\
\text { "Thou dearest lady Hildina, } \\
\text { O grant me peace and life!" }\end{array}$ \\
\hline $\begin{array}{l}33 . \\
\text { "Svá mikinn ok góðan } \\
\text { grið } \\
\text { Skalt pú [af mér] sjá: } \\
\text { Sem pú lét minn herran } \\
\text { Í bardaganum fá. }\end{array}$ & $\begin{array}{l}34 . \\
\text { "Like mykje og like god } \\
\text { grid } \\
\text { Skal du no sjaa, } \\
\text { Som du sjølv lét herren } \\
\text { min } \\
\text { I striden dykkar faa. }\end{array}$ & $\begin{array}{l}33 . \\
\text { "So much of good peace } \\
\text { shalt thou behold, } \\
\text { [To ease thee in thy pain; } \\
\text { As thou thyself wouldst give } \\
\text { my lord } \\
\text { Upon the battle-plain. }\end{array}$ \\
\hline $\begin{array}{l}34 . \\
\text { pú póttist par lítið um, } \\
\text { póat ek sá at, } \\
\text { [Ek] sá hans búkinn } \\
\text { blœða } \\
\text { pú kastaðir hans höfơi í } \\
\text { mitt fang } \\
\text { Ok vextir mér meira } \\
\text { mœðu.” }\end{array}$ & $\begin{array}{l}35 . \\
\text { Det tyktest deg lite, } \\
\text { endaa eg } \\
\text { Saag kroppen hans all i } \\
\text { blod, } \\
\text { Du kasta hans hovud i } \\
\text { mitt fang, } \\
\text { Daa voks det stort mitt } \\
\text { mod." }\end{array}$ & $\begin{array}{l}34 . \\
\text { "Little ye recked though } \\
\text { yonder I looked } \\
\text { On his body all bloodied } \\
\text { o'er, } \\
\text { But cast his head into my } \\
\text { arms, } \\
\text { And O but my heart was } \\
\text { sore!" }\end{array}$ \\
\hline $\begin{array}{l}35 . \\
\text { Nú pakt hon hefir } \\
\text { fölska hans } \\
\text { Bæði við mold ok stein: }\end{array}$ & $\begin{array}{l}36 . \\
\text { No tekt ho heve oska } \\
\text { hans } \\
\text { Baade med mold og } \\
\text { stein. }\end{array}$ & $\begin{array}{l}35 . \\
\text { And as she took both } \\
\text { mould and stone } \\
\text { On the embers for to } \\
\text { fling:- }\end{array}$ \\
\hline
\end{tabular}




\begin{tabular}{|l|l|l|}
\hline "pú skalt aldri meira & "Du skal aldri meir & "Never now shalt thou work \\
Konungsins barni valda & $\begin{array}{l}\text { konongsens } \\
\text { mein." }\end{array}$ & $\begin{array}{l}\text { Barn valda mein." } \\
\text { On the daughter of a king!" }\end{array}$ \\
\hline
\end{tabular}

Table 3. Hildina Ballad: attempts at translation (II)

\begin{tabular}{|c|c|c|}
\hline $\begin{array}{c}\text { J. E. POESTION } \\
(1914) \\
\end{array}$ & $\begin{array}{l}\text { NORAH KERSHAW } \\
(1921) \\
\end{array}$ & $\begin{array}{c}\text { EIGIL LEHMANN } \\
(1984) \\
\end{array}$ \\
\hline $\begin{array}{l}1 . \\
\text { Es war ein Jarl auf den } \\
\text { Orkneys; } \\
\text { Er holte beim Freund } \\
\text { Bescheid, } \\
\text { Ob wohl er aus den Nöten } \\
\text { Erlösen soll die Maid } \\
\quad \text { Und aus der Glasburg } \\
\text { nehmen. }\end{array}$ & $\begin{array}{l}1 . \\
\text { It was the Earl from } \\
\text { Orkney, } \\
\text { And counsel of his kin } \\
\text { sought he, } \\
\text { Whether he should the } \\
\text { maiden } \\
\text { Free from her misery. }\end{array}$ & $\begin{array}{l}1 . \\
\text { Da va jarlen tå Orknøyar } \\
\text { Han spurte sin frænde } \\
\text { um råd } \\
\text { Korte han skulde møyæ } \\
\text { Or vandará hennar få- } \\
\quad \text { (or glasborgjæ } \\
\text { henne taka): }\end{array}$ \\
\hline $\begin{array}{l}2 . \\
\text { "Nimm, lieber Freund, } \\
\text { aus der Glasburg } \\
\text { Die Maid du nur; dann } \\
\text { geht } \\
\text { Dein Ruf von Mund zu } \\
\text { Munde, } \\
\text { So lange die Welt } \\
\text { besteht." }\end{array}$ & $\begin{array}{l}2 . \\
\text { "If thou free the maid } \\
\text { from her gleaming hall, } \\
\text { O kinsman dear of mine, } \\
\text { Ever while the world shall } \\
\text { last } \\
\text { Thy glory still shall } \\
\text { shine." }\end{array}$ & $\begin{array}{l}2 . \\
\text { "Teker du møyæ or } \\
\text { glasborgjæ } \\
\text { Kjære frænde min fræg } \\
\text { Jamnan med denne } \\
\text { verdæ ho stender } \\
\text { Skal gjetord ganga um } \\
\text { deg.” }\end{array}$ \\
\hline $\begin{array}{l}3 . \\
\text { Der König kehrte vom } \\
\text { Kriege } \\
\text { Zurück in die Lande sein; } \\
\text { Verschwunden ist Frau } \\
\text { Hildina, } \\
\text { Die Stiefmutter steht } \\
\text { allein. }\end{array}$ & $\begin{array}{l}3 . \\
\text { Home came the king, } \\
\text { Home from the ship's } \\
\text { levy } \\
\text { The lady Hildina she was } \\
\text { gone, } \\
\text { And only her stepmother } \\
\text { there found he. }\end{array}$ & $\begin{array}{l}3 . \\
\text { Edlingjen kjemer av } \\
\text { leidang heim } \\
\text { — tôtte da skamm og } \\
\text { mein- } \\
\text { Burte stad var fru } \\
\text { Hildina } \\
\text { Øyden stod møyarstein. }\end{array}$ \\
\hline
\end{tabular}




\begin{tabular}{|c|c|c|}
\hline $\begin{array}{l}4 . \\
\text { "Wo immer er weilt in } \\
\text { den Landen, } \\
\text { —das schwör' ich! - ihr } \\
\text { Genoß } \\
\text { Soll hängen am höchsten } \\
\text { Baume, } \\
\text { Der Wurzeln je entsproß." }\end{array}$ & $\begin{array}{l}4 . \\
\text { "Be he in whatever land, } \\
\text { This will I prove true, } \\
\text { He shall be hanged from } \\
\text { the highest tree } \\
\text { That ever upward grew." }\end{array}$ & $\begin{array}{l}4 . \\
\text { "Kvar han er i londom } \\
\text { — detta kann sananst } \\
\text { på- } \\
\text { Han skal verta hengd i } \\
\text { Da hægsta tre } \\
\text { Som røter renna ifrå.” }\end{array}$ \\
\hline $\begin{array}{l}5 . \\
\text { “Kommt heim der Jarl } \\
\text { nach Orkney, } \\
\text { Dann wirkt's Sankt } \\
\text { Magnus aus, } \\
\text { Daß bort er auch immer } \\
\text { bleibe; } \\
\text { Drum zieh' aufs neue zum } \\
\text { Strauß!” }\end{array}$ & $\begin{array}{l}5 . \\
\text { "If the Earl but come to } \\
\text { Orkney, } \\
\text { Saint Magnus will be his } \\
\text { aid, } \\
\text { And in Orkney ever he } \\
\text { will remain- } \\
\text { Haste after him with } \\
\text { speed." }\end{array}$ & $\begin{array}{l}6 . \\
\text { Alt so gjever han } \\
\text { dronningjæ } \\
\text { Kinnpuster unde kinn } \\
\text { For sanno runno tåror } \\
\text { På hennar kvitare kinn. }\end{array}$ \\
\hline $\begin{array}{l}6 . \\
\text { Der Königin verseßt er } \\
\text { Hierauf einen } \\
\text { Backenstreich, } \\
\text { Daß über die weißen } \\
\text { Wangen } \\
\text { Ihr Tränen sließen } \\
\text { sogleich._- }\end{array}$ & $\begin{array}{l}6 . \\
\text { The King he stood before } \\
\text { his lady, } \\
\text { And a box on her ear gave } \\
\text { he,- } \\
\text { And all adown her lily } \\
\text { white cheeks } \\
\text { The tears did flow truly. }\end{array}$ & $\begin{array}{l}5 . \\
\text { “Kjemer til Orknøyar } \\
\text { jarlen } \\
\text { —-sante Magnus valdar } \\
\text { mein; } \\
\text { I Orknøyarne då bur han } \\
\text { sidan } \\
\text { Du fare i leidang enn'.” }\end{array}$ \\
\hline $\begin{array}{l}7 . \\
\text { Der Jarl tritt zu Hildina } \\
\text { Und streichelt die Wange } \\
\text { ihr: } \\
\text { "Wem wünschest den } \\
\text { Tod du lieber, } \\
\text { Dem Vater oder mir?" }\end{array}$ & $\begin{array}{l}7 . \\
\text { The Earl he stood before } \\
\text { Hildina, } \\
\text { And a pat on her cheek } \\
\text { gave he,- } \\
\text { "O which of us two } \\
\text { wouldst thou have lie } \\
\text { dead, } \\
\text { Thy father dear of me? }\end{array}$ & $\begin{array}{l}7 . \\
\text { Inn kjemer Orknøy- } \\
\text { jarlen } \\
\text { Og klappar si Hildina } \\
\text { unde kinn: } \\
\text { "Kvare vilde du feigan } \\
\text { vera } \\
\text { Meg elder fa'er din? }\end{array}$ \\
\hline $\begin{array}{l}8 . \\
\text { "Des Todes sei lieber } \\
\text { mein Vater } \\
\text { Mit all seiner Sippe dann, }\end{array}$ & $\begin{array}{l}8 . \\
\text { "I would rather see my } \\
\text { father doomed, } \\
\text { And all his company, }\end{array}$ & $\begin{array}{l}8 . \\
\text { "Helder vilde eg feigan } \\
\text { vera } \\
\text { Far min og alt han å - }\end{array}$ \\
\hline
\end{tabular}




\begin{tabular}{|c|c|c|}
\hline $\begin{array}{l}\text { Daß lang ich mit meinem } \\
\text { Gebieter } \\
\text { Auf Orkney herrschen } \\
\text { kann. }\end{array}$ & $\begin{array}{l}\text { If so my own true lord } \\
\text { and I } \\
\text { May long rule in Orkney. }\end{array}$ & $\begin{array}{l}\text { So skal eg og herren min } \\
\text { Yve Orknøyar lengje rå.” }\end{array}$ \\
\hline $\begin{array}{l}9 . \\
\text { Doch nehmet ein Roß } \\
\text { und reitet } \\
\text { Zum Strande, damit Ihr } \\
\text { vielleicht, } \\
\text { Wenn freundlich Ihr } \\
\text { grüßt meinen Vater, } \\
\text { Euch noch miteinander } \\
\text { vergleicht.” }\end{array}$ & $\begin{array}{l}9 . \\
\text { "Now do thou take in } \\
\text { hand thy steed, } \\
\text { And ride thou down to } \\
\text { the strand; } \\
\text { And do thou greet my } \\
\text { sire full blithely, } \\
\text { And gladly will he clasp } \\
\text { thy hand." }\end{array}$ & $\begin{array}{l}9 . \\
\text { "No skal De taka Dykk } \\
\text { øyk å hånd } \\
\text { Og ri’a Dykk ned til } \\
\text { strand } \\
\text { Og helsa far minom } \\
\text { avar-blidt } \\
\text { Gjedna kjem han i } \\
\text { Dykkar band." }\end{array}$ \\
\hline $\begin{array}{l}10 . \\
\text { Dem Jarl entgegnet der } \\
\text { König } \\
\text { —er war nicht so hart } \\
\text { gesinnt-: } \\
\text { "Was habt Ihr wohl als } \\
\text { Buße } \\
\text { Zu geben mir für mein } \\
\text { Kind?" }\end{array}$ & $\begin{array}{l}10 . \\
\text { The King he now made } \\
\text { answer } \\
\text { —-So sore displeased was } \\
\text { he- } \\
\text { "In payment for my } \\
\text { daughter } \\
\text { What will thou give to } \\
\text { me." }\end{array}$ & $\begin{array}{l}10 . \\
\text { Då svara ‘om konungjen } \\
\text { — so mykje rann honom } \\
\text { i hug- } \\
\text { "Kva heve du å gjeva } \\
\text { meg } \\
\text { Atter i dotterbot?" }\end{array}$ \\
\hline $\begin{array}{l}11 . \\
\text { “Wohl dreizig Mark ich } \\
\text { Euch gerne } \\
\text { In rotem Golde geb’; } \\
\text { Auch sollt einen Sohn Ihr } \\
\text { niemals } \\
\text { Vermissen, so lang ich } \\
\text { leb'.” }\end{array}$ & $\begin{array}{l}11 . \\
\text { "Thirty marks of the red } \\
\text { gold, } \\
\text { This to thee will I give, } \\
\text { And never shalt thou lack } \\
\text { a son } \\
\text { As long as I may live." }\end{array}$ & $\begin{array}{l}11 . \\
\text { "Tretti merker med } \\
\text { raude gull } \\
\text { Skal du hjå meg få } \\
\text { Og aldri å vera sonalaus } \\
\text { So lengje som eg leva } \\
\text { må.” }\end{array}$ \\
\hline $\begin{array}{l}12 . \\
\text { Gar lange stand der König } \\
\text { Und lange sah er ihn an. } \\
\text { "Du wärst schon wert mir } \\
\text { viel Söhne; } \\
\text { Drum schlag' ich ein; } \\
\text { wohlan!" }\end{array}$ & $\begin{array}{l}12 . \\
\text { Now long stood the King, } \\
\text { And long on the Earl } \\
\text { gazed he:- } \\
\text { "O thou art worth a host } \\
\text { of sons; } \\
\text { Thy boon is granted } \\
\text { thee." }\end{array}$ & $\begin{array}{l}12 . \\
\text { No lengje sto han } \\
\text { konungjen } \\
\text { Og lengje på han såg: } \\
\text { "Jamgod er du med } \\
\text { vaksen son } \\
\text { Og havande mann til } \\
\text { måg." }\end{array}$ \\
\hline
\end{tabular}




\begin{tabular}{|c|c|}
\hline & $\begin{array}{l}\text { 12b. } \\
\text { "Vil du vera i sona-stad } \\
\text { Og ganga meg til handa, } \\
\text { Då ræddest eg ingjen } \\
\text { fiendsmann } \\
\text { Um han kjøme hjå meg } \\
\text { til landa." }\end{array}$ \\
\hline $\begin{array}{l}\text { 13. } \\
\text { Hilugi sprach dagegen } \\
\text { —Schmach ih, daß er es } \\
\text { tat!-: } \\
\text { "Nehmt Buße für Hildina } \\
\text { Nur so, wie ich Euch rat: }\end{array}$ & $\begin{array}{l}13 . \\
\text { Då svara han Illugje } \\
\text { —-Herregud gjeve } \\
\text { honom skamm!- } \\
\text { "Tak De bot fyre Hildina } \\
\text { Som eg vil leggja Dykk } \\
\text { fram. }\end{array}$ \\
\hline $\begin{array}{l}14 . \\
\text { An Pferden und an } \\
\text { Ochsen, } \\
\text { Was taugt als } \\
\text { Pfluggespann, } \\
\text { An Pferden und an } \\
\text { Ochsen, } \\
\text { Was Egge ziehen kann.” }\end{array}$ & $\begin{array}{l}14 . \\
\text { Hesten kvar og } \\
\text { firføttingjen } \\
\text { Som ganga kann i slogje, } \\
\text { Hesten kvar og } \\
\text { firføttingjen } \\
\text { Som ganga kann i } \\
\text { plogje." }\end{array}$ \\
\hline $\begin{array}{l}15 . \\
\text { Es steht der Jarl gar lange, } \\
\text { Blickt lang auf den König } \\
\text { hin: } \\
\text { "Das können die Orkneys } \\
\text { nimmer, } \\
\text { So lang ich am Leben } \\
\text { bin." }\end{array}$ & $\begin{array}{l}15 . \\
\text { Stender no lengje jarlen } \\
\text { Og lengje på han såg: } \\
\text { "Detta ber ikkje } \\
\text { Orknøyar } \\
\text { So lengje som eg leva } \\
\text { må." }\end{array}$ \\
\hline $\begin{array}{l}16 . \\
\text { "Dein Vater will nichts } \\
\text { wissen } \\
\text { Von billigent Vergleich. } \\
\text { Wie ich's gedacht hab', } \\
\text { spielte } \\
\text { Hilugi uns diesen } \\
\text { Streich.” }\end{array}$ & $\begin{array}{l}16 . \\
\text { "No teker'an ikkje ved } \\
\text { samsått } \\
\text { Konungjen fa'er din, } \\
\text { No meinar eg at han } \\
\text { Illugjen } \\
\text { På onnorleis åtgjerd } \\
\text { vinn.” }\end{array}$ \\
\hline
\end{tabular}




\begin{tabular}{|c|c|}
\hline $\begin{array}{l}17 . \\
\text { Dem Jarl darauf entgegnet } \\
\text { Hildina aus ihrem Haus: } \\
\text { "Dann schreitet lieber } \\
\text { zum Kampfe, } \\
\text { fällt er wie immer aus!" }\end{array}$ & $\begin{array}{l}17 . \\
\text { Då svarar honom fru } \\
\text { Hildina } \\
\text { I same sinne som so: } \\
\text { "Da må de slåst i } \\
\text { bardagje } \\
\text { Og koma kva koma må. }\end{array}$ \\
\hline $\begin{array}{l}18 . \\
\text { Der Jarl geht auf den } \\
\text { Kampfplaß } \\
\text { Und ordnet seine Schar, } \\
\text { Die kecken Orkney- } \\
\text { Mannen } \\
\text { [erprobt in Sturrm und } \\
\text { Gefahr] }\end{array}$ & $\begin{array}{l}18 . \\
\text { No jarlen gjenger å } \\
\text { vollen fram } \\
\text { Og kannar sine menn. } \\
\text { Gjæve skjeggjar i } \\
\text { Orknøyom } \\
\text { Verja seg anna sinn. }\end{array}$ \\
\hline $\begin{array}{l}19 . \\
\text { "Es drang in deine Felder } \\
\text { Der König ein voll } \\
\text { Wucht, } \\
\text { Wohledle Männer treibt } \\
\text { auch } \\
\text { Sein Freund schon in die } \\
\text { Flucht." }\end{array}$ & $\begin{array}{l}19 . \\
\text { "No er Illugjen komen } \\
\text { Inn på vollen din. } \\
\text { Frænden hans fa' er din } \\
\text { løyper } \\
\text { Velborne Orknøy- } \\
\text { menn.” }\end{array}$ \\
\hline $\begin{array}{l}20 . \\
\text { Hildina geht auf das } \\
\text { Schlachtfeld, } \\
\text { Den Vater anzuflehn: } \\
\text { "Seid menschlich nun und } \\
\text { laßt nicht } \\
\text { Mehr Männer zugrunde } \\
\text { gehn!" }\end{array}$ & $\begin{array}{l}20 . \\
\text { Hildina gjenger i vollen } \\
\text { fram } \\
\text { Og talar til fa'eren sin: } \\
\text { "Fa'er De gjere da åv } \\
\text { manndom Dykkar } \\
\text { De spille 'kje meire } \\
\text { menn." }\end{array}$ \\
\hline $\begin{array}{l}21 . \\
\text { Jedoch Hilugi —-Schmach } \\
\text { ihm!- } \\
\text { Er wendete sogleich ein: } \\
\text { "Da muß vorerst dein } \\
\text { Freund noch, } \\
\text { Der Jarl, gefallen sein." }\end{array}$ & $\begin{array}{l}21 . \\
\text { No svarar han Illugje } \\
\text { —Herregu' gjeve honom } \\
\text { skamm- } \\
\text { "Ikkje fyrr jarlen herren } \\
\text { din } \\
\text { Fyrst er fallen han." }\end{array}$ \\
\hline
\end{tabular}




\begin{tabular}{|l|l|l|}
\hline 22. & 22. \\
Er fiel, zu Tod verwundet. & So gav han jarlen da \\
Den Kopf warf in den & hoggje \\
Schoß & Som ingjen mann kunde \\
Hilugi selber Hildinen. & grøda, \\
Da ward ihr Grimm wohl & Han kasta hans hovud i \\
groß. & fangje hennar \\
& Då gjordest for stor \\
& hennar møda. \\
\hline 23. & 23. \\
"Versprech sie mir, dann & Du heve lova meg \\
folg ich & hjonagift \\
Euch kühn auch außer & Dann tid eg fór åv lande. \\
Land. & Gjev meg no fruva \\
Gebt mir Hildina zum & Hildina \\
Weibe & Med gull og med \\
Und Gold als & festarbande. \\
Unterpfand!" & \\
\hline 24. & "Geduld, bis das Kind & Fyst ho heve da jarlsbarn \\
geboren & bore \\
Und Kleider trägt, mein & A da kann sine klæ’e \\
Freund! & bera \\
Dann soll Hildina & Då skal ho fruva Hildina \\
handeln, & Åt sjølvs sinom vilja \\
Wie ihr’s am besten & gjera. \\
scheint.” & & \\
\hline 25. & 25. \\
Hildina liegt auf dem & Hildina ligger på \\
Teppich & bruratjeld \\
Und weint sich die Augen & Auga tårar og græter \\
krank; & Medan dei bur til \\
Dann mischt sie für die & brudlaupsbord \\
Hochzeit & I drikka dåe ho læter. \\
Schlafkräuter in den & \\
Trank. & \\
\hline & \\
\hline & & \\
\hline
\end{tabular}




\begin{tabular}{|c|c|}
\hline $\begin{array}{l}26 . \\
\text { Nun bittet Frau Hildina: } \\
\text { "O, lieber Vater, mein, } \\
\text { Erlaub mir einzuschenken } \\
\text { Und nachzufüllen den } \\
\text { Wein!” }\end{array}$ & $\begin{array}{l}26 . \\
\text { Inn so kjemer ho } \\
\text { Hildina } \\
\text { Og skjer Fa'eren sin: } \\
\text { "Fa'er De gjeve meg } \\
\text { løyve } \\
\text { A skjenkja og bjoda vin." }\end{array}$ \\
\hline $\begin{array}{l}27 . \\
\text { "Schenk ein den Wein } \\
\text { und fülle } \\
\text { Ihn nach auch, willst du's } \\
\text { gern; } \\
\text { Doch denk an den Jarl } \\
\text { nicht weiter, } \\
\text { An deinen gütigen } \\
\text { Herrn!" }\end{array}$ & $\begin{array}{l}27 . \\
\text { Du skal hava løyve mitt } \\
\text { Te skjenkja og bjoda vin; } \\
\text { Tenk då ikkje på jarlen } \\
\text { Dan gode herren din.” }\end{array}$ \\
\hline $\begin{array}{l}28 . \\
\text { “Sollt' an den Jarl ich } \\
\text { denken, } \\
\text { An meinen gütigen } \\
\text { Herrn, } \\
\text { Liegt schädlichen Trunk } \\
\text { zu reichen } \\
\text { Dem Vater mit doch } \\
\text { fern.” }\end{array}$ & $\begin{array}{l}28 . \\
\text { Um eg so skulde tenkja } \\
\text { På jarlen, go’ herren min } \\
\text { So munde eg ingjæ făr- } \\
\text { skål bera } \\
\text { For kjære fa'er min.” }\end{array}$ \\
\hline $\begin{array}{l}29 . \\
\text { Dies tat auch Frau } \\
\text { Hildina; } \\
\text { Sie trug den Met herein } \\
\text { Und schläferte fest den } \\
\text { Vater } \\
\text { Und all die andern dort } \\
\text { ein. }\end{array}$ & $\begin{array}{l}29 . \\
\text { Da gjorde ho fruva } \\
\text { Hildina } \\
\text { Ho bar dan mjø'en åt } \\
\text { So svæver ho fyst fa'er } \\
\text { sin } \\
\text { Og kvar som inne sat. }\end{array}$ \\
\hline $\begin{array}{l}30 . \\
\text { Dann trug sie aus der } \\
\text { Halle } \\
\text { Hinaus noch Mann für } \\
\text { Mann }\end{array}$ & $\begin{array}{l}30 . \\
\text { Da gjorde ho fruva } \\
\text { Hildina } \\
\text { Ho bar deim or hallæ } \\
\text { burt, }\end{array}$ \\
\hline
\end{tabular}




\begin{tabular}{|c|c|}
\hline $\begin{array}{l}\text { Und legte bei den Tore } \\
\text { Zuäußert Feuer an. }\end{array}$ & $\begin{array}{l}\text { Sidan lagde ho glodhaug } \\
\text { I ytste gateport. }\end{array}$ \\
\hline $\begin{array}{l}31 . \\
\text { Hilugi weiß nichts von } \\
\text { allem; } \\
\text { Es kamen des Brandes } \\
\text { Loh'n } \\
\text { Zur Bodenhaus-Tür und } \\
\text { erreichten } \\
\text { Sein kurzes Seidenhemd } \\
\text { schon. }\end{array}$ & $\begin{array}{l}31 . \\
\text { Ikkje visste han Illugje } \\
\text { Åv seg fyrr enn då } \\
\text { Elden var komen i } \\
\text { lofthusdør } \\
\text { Og i silkjeserkjen hans } \\
\text { små. }\end{array}$ \\
\hline $\begin{array}{l}32 . \\
\text { Da springt empor Hilugi, } \\
\text { [Sieht sie und spricht zu } \\
\text { ihr:] } \\
\text { "O teuerste Frau Hildina, } \\
\text { Schenk Leben und } \\
\text { Frieden mir!" }\end{array}$ & $\begin{array}{l}32 . \\
\text { No løyper fram han } \\
\text { Illugje } \\
\text { Og feller for Hildina } \\
\text { kne: } \\
\text { "Du nenne da, fruva } \\
\text { Hildina, } \\
\text { Du gjeve meg liv og gre" }\end{array}$ \\
\hline $\begin{array}{l}33 . \\
\text { "So viel und guter Frieden } \\
\text { Soll dir gewährt nun sein, } \\
\text { Wie meinem Herrn in der } \\
\text { Schlacht du } \\
\text { Selbst ließest angedeih'n. }\end{array}$ & $\begin{array}{l}33 . \\
\text { "So mykje og godig } \\
\text { Gre skal du sjă, } \\
\text { Som du lét min herre } \\
\text { I bardagen få." }\end{array}$ \\
\hline $\begin{array}{l}34 . \\
\text { Dir schien's sogar ein } \\
\text { Geringes, } \\
\text { Daß ich ihn sah im Blut; } \\
\text { Du warfst sein Haupt in } \\
\text { den Schoß mir... } \\
\text { Da ward mir noch } \\
\text { schwerer zu Mut." }\end{array}$ & $\begin{array}{l}34 . \\
\text { "Du tôtte da lite då, at } \\
\text { eg } \\
\text { Såg istad hans bukjen } \\
\text { bløda; } \\
\text { Dei kasta hans hovud i } \\
\text { mitt fang, } \\
\text { Da vart meg for stor ei } \\
\text { møda." }\end{array}$ \\
\hline $\begin{array}{l}35 . \\
\text { Dann hat sie seine } \\
\text { Falschheit }\end{array}$ & $\begin{array}{l}35 . \\
\text { So takte ho yve osko } \\
\text { hans }\end{array}$ \\
\hline
\end{tabular}




\begin{tabular}{|l|l|l|}
\hline Bedeckt mit Erde und & & Både med mold og stein: \\
Stein. & & "Du skal aldri meir \\
"Du sollst einem & konungsens \\
Königskinde & dotter valda mein.” \\
Nie mehr zum Schaden & \\
sein!” & \\
\hline
\end{tabular}

Table 4. Hildina Ballad: attempt at reconstruction/translation

\section{GRAEME DAVIS}

(2007)

Once upon a time the Earl of Orkney asked his brother "From out her glass pavilion should I steal our King's daughter?" "My brother if you take this maiden from out her glass pavilion Your deed shall be remembered for years a million million.” Thus when the King came home from viking voyage a winner The step-mother was still at home, but there was no Hildina.

"I swear by all that's holy that wherever he may be

I'll hang him by his neck from the very highest tree."

To good St Magnus' church in Orkney fled the Earl,

To Orkney sped the King, to save his little girl.

Meeting the married lady there he boxed her round the ears

Soon down her white cheeks there flowed a flood of tears.

The Earl embraced Hildina, and kissed her on the cheek,

"My darling wife, between us two, whose death would you now seek?"

"Not to my father but to you I swore my lasting vow,

And so by that we both may rule, us two in Orkney now."

"Go to your horse and overtake my father on the beach,

Greet him kindly, clasp hands, his blessing to beseech.”

The King made a stern reply, his anger did not falter,

"I want to know what bride price can you give me for my daughter?"

"Thirty marks of burnished gold shall I unto you give,

And you will never lack a son for as long as I may live.” 
Long stood the King, gazed on the Earl for long,

"You're worth a thousand sons my man, though what you did was wrong."

Now among the King's companions was the swarthy Hilunge,

To wed the beauteous Hildina his dream for many a day.

Again and again and craftily Hilunge spoke to the King,

Again and again the King did listen, once more to this thing.

Now for a long time the King looked at the Earl standing near

"You may not Orkney; a long time ago I betrothed my daughter dear."

"I will take nothing against his will from the King your father,

Instead to give Hilunge his rights, that would I rather."

Hildina looked from the one to the other, turned pale,

One would die in the fight, that fate would not fail.

Now the Earl stepped forward onto the duelling ground

And the King turned his face from Orkney, looked around.

"Now one of us must die, 'tis either thee or me,"

The blows rained down, down fell the Earl Orkney.

Now Lady Hildina steps on the grass where soon a corpse must lie,

"Father by all that's holy do not let a brave man die."

But Hilunge answered her: "Call Odin's maidens here,

For death draws nigh the Earl, this man your husband dear."

Now the Earl felt the axe bite through his neck, a clean kill

Hilunge threw the head into her arms; she grew more angry still.

"You promised me marriage if I voyaged far from our land

Now with golden dowry and strong vows give me Hildina's hand."

Now were her eyes downcast as he looked upon the king

For the lady Hildina against her will must take a golden ring.

Soon that time came, though Hildina wished it never,

With that man to be joined, husband and wife forever.

Now Hildina asked her father "May I serve the wine,

Choose who will get the best, who the worst, when we come to dine?"

"Both the best and the worst as you rightly think,

Both earls and freemen this day must drink."

A drugged wine she gave them, both to earls and to freemen,

Their eyes were heavy, sleep came over them. 
Then the Lady Hildina went in, her face was set, She saw her father and the guests asleep, on the benches where they sat.

Then the Lady Hildina went in, dragged her father across the floor,

Laid him on the grass outside and fastened close the door.

Now Hilunge awakes as the fire begins to rage,

The smoke is black and thick, the banquet hall a cage.

Now a scream breaks from the throat of Hilunge,

"Oh Lady Hildina, let me live another day."

"So may you cry out, now you should believe,

That same mercy you showed in the battle you shall receive, You did not care for him or me, that was clear for all to see,

That you threw his head at me, that angered me.

Now receive a heavy fate, for soon to death you yield,

The king cannot help you now, on this battlefield."

All this for once upon a time the Earl of Orkney asked his brother

"From out her glass pavilion should I steal our King's daughter?"

\section{Some concluding remarks}

With two serious attempts at reconstruction —or three, if we also take Davis's version into consideration - and six attempts at translation, the Hildina Ballad still remains a text that is chiefly interesting from the linguistic point of view. The aim of those translations and reconstructions has been to try to understand the original story and, in some instances (Munch, Grundtvig, Olrik, Bugge), to get an idea of how it may have sounded in Old Norse. This overlooks the fact that the ballad as we know it is just a local Norn product, not necessarily an Old Norse relic. That is why, understandably, I have included Sophus Bugge's Norse version among the translations - and not the reconstructions - of the ballad. In this sense, the following statement of Grüner-Nielsen (1939: 165) is still valid: 
Den Omstændighed, at Professor Marius Hægstad o.1900 af Hensyn til en af Sophus Bugge bebudet Publikation lod sig nøje med at udgive og vurdere Hildinavisen mere som shetlandsk Sprogmindesmærke end som vestnordisk Folkevise, har vist bevirket, at Visen siden ligesom er gaaet i Glemme indenfor den nordiske Viseforskning, og at man paa Forhaand har betragtet Visen som et folkelig Produkt, der højst havde lokal Interesse.

If this piece of Norn oral tradition is to be taken at face value and treated as a highly interesting anthropological ${ }^{22}$ —and not merely linguistic - document, then it should be interpreted within the cultural and chronological context in which it was discovered and written down, as well as within the wider concept of det norrøne folkeviseumrådet, as Liestøl (1937) calls it. As some reputed scholars like Lord (2000) or Colbert (1989) state, looking for a supposed original when dealing with dynamic, oral compositions is not only a waste of time, but also representative of a sort of disdain for the composition to be studied and understood. Oral narrative is constitutive of social life itself or, as Niles (1999: 19) puts it, "the idea of poetry as a voiced social transaction is one of the foundational elements of the art of Homo narrans". Given this, a literaryanthropological — and not purely linguistic — approach to the Hildina Ballad is necessary if we really wish to understand why this ballad was still preserved and recited in Norn after centuries of Scottish domination in the Orkney and Shetland Islands.

This literary-anthropological approach would make it possible to unveil the issues of cultural identity that might lie behind the Hildina Ballad. As Niles (1999: 2) also states, "it is chiefly through storytelling that people possess a past", and the past is one of the main elements used to build up identities. In the case of the Hildina Ballad, it seems quite clear that this product of Norn oral tradition can be interpreted as a symbol of cultural identity, although we have not yet found its actual significance: May the ballad have been used, in the ritualized milieu of its recitation, to strengthen cultural links with Scandinavia within a context of Scottish rule? In this sense, the study of and quest for Nordic analogues of the ballad would be very enlightening as to how Scandinavian that late Norn product still was, i.e. how Scandinavian the Shetlandic society of Foula still was. On the other hand, the ballad might be also interpreted as a symbol of

\footnotetext{
${ }^{22}$ Note that we use the adjetive anthropological, not ethnographical, as we think that the study of the Hildina Ballad poses interesting questions about the dynamics of buman oral culture and its implications in other areas such as identity or politics, and not only questions of mere local nature.
} 
confrontation of the Shetland and Orkney Islands against Norway. The Orcadian jarl dying at the hands of the Norwegian counsellor of a Norwegian king after abducting a Norwegian princess may symbolize a social vindication of an identity that was no longer Norwegian, but neither was it Scottish; it was simply Norn. If this was so, we may have here an example of an underlying political conflict developing into a love story or a story of revenge, as Solberg (2008: 131) explains concerning Medieval Scandinavian ballads in general.

It is almost impossible to know when the Hildina Ballad was composed for the first time. This is, if one can speak of a very "first time" when dealing with what is possibly an amalgam of many stories told at different times. The only thing we know for sure is that the ballad that was still recited in 1774 was a rather worn out version, not only because George Low "could not procure a literal translation of the ballad" (Low 1879: 113), ${ }^{23}$ but also because "the disorder of some stanzas" shows that the ballad was no longer complete by the time he wrote it down (Low 1879: 107). On the other hand, the fact that it does not have any refrains is a typical feature of those ballads which have lost their connexion with dancing (Christophersen 1952: 6), and a ballad with no dance is somehow just a fossil. ${ }^{24}$

Fortunately, we have at least a terminus post quem and a terminus ante quem that make it possible to estimate a feasible date of composition for the Hildina Ballad as we know it today. As Anderson (1979 [1873]) already pointed out in his introduction to the English translation of the Orkneyinga Saga, the mention of Saint Magnus of Orkney (sante Maunis) in stanza 5 of the ballad implies that it cannot have been composed before Magnús Erlendsson's canonisation in 1135. That would be the terminus post quem. On the other hand, the name Hildina is a variation of the Old Norse Hildr/Hild, or maybe a form influenced by the name Helena, as Hægstad (1900: 85) remarks. However, it should be considered that, according to Indrebø (1951: 323), between the years 1530 and 1800, but especially between 1600 and 1800, there was a stort namne-brot in the names of Norwegian origin. One of these changes was the addition of the ending

\footnotetext{
${ }^{23}$ This most likely implies that William Henry could not give him a literal translation of the ballad, as he only knew it by heart without understanding it completely. In this case, we are facing an example of what language death theories call the 'folklorization' phase of a language on its way to extinction (Crystal 2000).

${ }^{24}$ That Faroese ballads are still danced is one of the main reasons to explain their popularity among folklorists, as they show the literary conditions in the Middle Ages in a living way (Müller 1994: 96).
} 
-ina to many female names (Hansina, Larsina, Bolina, Olina, Malina, Talina, Gorina, or Gurina, etc.). Although Indrebø does not mention the name Hildina in his examples, it is clear that it belongs to this category. The name Hildina would then imply that our ballad may have started to be performed in its current form from about 1530 or most likely from 1600, i.e. just 174 years before William Henry recited it for George Low. That would be its terminus ante quem. Thus, despite the fact that it was not a very old ballad in 1774, it was already quite worn out, as mentioned before. A fast process of decay indeed.

Can the search for analogues of the Hildina Ballad help us find its moment of splendour from a creative point of view and relate it to the social, economical, and cultural conditions of the Orkney and Shetland Islands at that time? Would it be possible to compare that hypothetical moment of splendour with the sociocultural conditions of 1774 , when the ballad was written down by George Low? If the answer is affirmative, then it could be possible to learn much about the relationship between the so-called - from a Scandinavian perspectiveWestern Islands and Scandinavia in the eighteenth century, and how it influenced issues of cultural identity. It would allow us to explore to which extent oral narrative "is and for a long time has been the chief basis of culture itself” (Niles 1999: 2).

\section{References}

Anderson, J. ed. 1973 [1873]: The Orkneyinga Saga. Edinburgh, The Mercat Press.

Baranauskiené, R. 2007: Reflections of Celtic Literary Tradition in Shetlandic 'Hildinavisen'. Zmogus ir zodis (Man and the Word) 9.2: 72-82.

Barnes, M. 1984a: Norn. Scripta Islandica 35: 23-42.

Barnes, M. 1984b: Orkney and Shetland Norn. In P. Trudgill ed. Language in the British Isles. Cambridge, Cambridge University Press: 352-366.

Barnes, M. 1998: The Norn Language of Orkney and Shetland. Lerwick, The Shetland Times Ltd.

Barnes, M. 2004: Norn, the One-time Scandinavian Language of Orkney and Shetland. Íslensk Mál 26: 49-81.

Bugge, E. 2005: Jakob Jakobsens Etymologisk ordbok over det norrøne sprog på Shetland (1908-1921). Nordica Bergensia 33: 21-42.

Christiansen, R. Th. 1938: Sudrøy-norn. Maal og Minne 1.2: 1-27.

Christophersen, P. 1952: The Ballad of Sir Aldingar. Its Origin and Analogues. London, Oxford University Press. 
Colbert, D. 1989: The Birth of the Ballad. The Scandinavian Medieval Genre. Stockholm, Sveskt Visarkiv.

Collingwood, W. G. 1908: The Ballad of Hildina. Orkney and Shetland Miscellany of the Viking Club, I.VI: 211-216.

Crystal, D. 2002: Language Death. Cambridge, Cambridge University Press.

Davis, G. 2007: The Early English Settlement of Orkney and Shetland. Edinburgh, Birlinn.

Entwistle, W. J. 1969: European Balladry. Oxford, Oxford University Press.

Erlingsson, D. 1975: Illuga saga og Illuga dans. Gripla I: 9-42.

Faulkes, A. ed. 1991: Snorri Sturluson. Edda: Háttatal. Oxford, Clarendon Press (ed. A. Faulkes).

Faulkes, A. ed. 1998: Snorri Sturluson. Edda: Skáldskaparmál. 2 vols. London, Viking Society for Northern Research/University College London.

Finnegan, R. 1991: Oral Traditions and the Verbal Arts: A Guide to Research Practice. London, Routledge.

Flom, G. T. 1903: Review of Marius Hægstad: Hildinakvadet, med utgreiding um det norske maal paa Shetland i eldre Tid. American Journal of Philology 24.4: 465-468.

González Campo, M. 2008: Baladas épicas feroesas (Antología bilingüe). Madrid, Miraguano Ediciones.

Graham, J. J. \& L. I. Graham eds. 1998: A Shetland Anthology. Lerwick, Shetland Publishing Co.

Grüner-Nielsen, H. 1939: Den Shetlandske Hildina-Vise og Sophus Bugges Tolkning. Heidersskrift til Gustav Indrebø på femtiårsdagen 17. November 1939. Bergen, A. S. Lunde \& Co.: 139-165.

Gưmundsson, F. ed. 1965: Orkneyinga saga. Reykjavík, Hið Íslenzka Fornritafélag.

Helgason, J. \& A. Holtsmark eds. 1941: Háttalykill enn forni. Copenhaguen, Ejnar Munksgaard.

Heusler, A. 1922: Über die Balladendichtung des Spätmittelalters, namentlich in Skandinavischen Norden. Germaniscb-Romanische Monatsschrift 10: 16-31.

Hægstad, M. 1900: Hildinakvadet med utgreiding um det norske maal paa Shetland i eldre tid. Oslo, Grøndal \& Søns Bogtrykkeri.

Hægstad, M. 1901: Hildinakvadet. Syn og Segn: 1-14.

Hægstad, M. 1910: Upphavet til ordet 'norsk'. Maal og Minne 2: 51-52.

Indrebø, G. 1951: Norsk målsoga. Bergen, John Griegs Boktrykkeri (P. Hovda \& P. Thorson eds.).

Jakobsen, J. 1897: Det norrøne sprog på Shetland. Copenhague, Wilhelm Priors Hofboghandel.

Jakobsen, J. 1928-1932: Etymological Dictionary of the Norn Language in Shetland. Londres/Copenhague, David Nutt/Vilhelm Prior (Reprinted: New York, AMS Press, 1985).

Jesch, J. 2005: Literature in Medieval Orkney. In O. Owen ed. The World of Orkneyinga Saga. Kirkwall, The Orcadian Limited: 11-24. 
Jesch, J. 2006a: Norse Literature in the Orkney Earldom. In I. Brown, T. Owen Clancy, S. Manning \& M. Pittock eds. The Edinburgh History of Scottish Literature, Vol. I: From Columba to the Union (until 1707). Edinburgh, Edinburgh University Press: 77-82.

Jesch, J. 2006b: Norse Myth in Medieval Orkney. In J. McKinnell, D. Ashurst \& D. Kick eds. The Fantastic in Old Norse/Icelandic Literature. Sagas in the British Isles. Prepint Papers of the Thirteenth International Saga Conference, Durbam and York $6^{\text {th }}$ 12 ${ }^{\text {th }}$ August, 2006. Vol. 1. Durham, The Centre for Medieval and Renaissance Studies/Durham University: 435-444.

Jonsson, B. R., S. Solheim \& E. Danielson 1978: The Types of the Scandinavian Medieval Ballad. Oslo, Universitetsforlaget.

Jónsson, G. ed. 1954: Fornaldarsögur Norðurlanda. 4 vols. Reykjavík, Íslendingasagnaútgáfan.

Kershaw, N. 1921: Stories and Ballads of the Far Past. Cambridge, Cambridge University Press.

Kruken, K. ed. 2004: Sophus Bugges brev. 3 vols. Øvre Ervik, Alvheim og Eide.

Leach, H. G. 1946: A Pageant of Old Scandinavia. New York, Princeton University Press/American-Scandinavian Foundation.

Lehmann, E. 1984: Hildina-kvaedet: Ein etterøknad og ei tolking. Frå Fjon til Fusa: 760 .

Liestøl, K. 1915: Norske trollvisor og norrøne sogor. Oslo, Olaf Norlis Forlag.

Liestøl, K. 1937: Det norrøne folkeviseumrådet. Maal og Minne: 81-129.

Lord, A. B. 2000: The Singer of Tales. Cambridge (Mass.), Harvard University Press (S. Mitchell \& G. Nagy eds.).

Low, G. 1879: A Tour through the Islands of Orkney and Schetland Containing Hints Relative to their Ancient, Modern and Natural History Collected in 1774. Kirkwall, William Peace \& Son (J. Anderson ed.).

Marwick, H. 1929: The Orkney Norn. London, Oxford University Press.

Moore, D. W. 2005: The Other British Isles: A History of Shetland, Orkney, The Hebrides, Isle of Man, Angelsy, Scilly, Isle of Wight and the Channel Islands. Jefferson (North Carolina), McFarland \& Company.

Müller, U. 1994: The Living Tristan: The Faroese 'Tistram-Ballad'. Tristania XV: 8798.

Munch, P. A. 1839: Geographiske og historiske notitser om Orknoërne og Hetland. Samlingar til det Norske Folks Sprog og Historie 6: 79-133, 475-524.

Nauerby, T. 1996: No Nation is an Island. Language, Culture, and National Identity in the Faroe Islands. Århus, SNAI-North Atlantic Publications/Aarhus University Press.

Niles, J. D. 1999: Homo Narrans. The Poetics and Anthropology of Oral Literature. Philadelphia, University of Pennsylvania Press. 
Pálsson, H. 1984: A Florilegium in Norse from Medieval Orkney. In A. Fenton \& H. Pálsson eds. The Northern and Western Isles in the Viking World. Survival, Continuity and Change. Edinburgh, John Donald Publishers: 258-264.

Pálsson, H. 1998: Snorri Sturluson and the Everlasting Battle. In H. Fix ed. Snorri Sturluson: Beiträge zu Werk und Rezeption. Berlin, Walter de Gruyter: 44-56.

Poestion, J. E. 1914: Das Lied von Hildina. Zeitschrift für den deutschen Unterricht 28 part IX: 592-595.

Renaud, J. 1988: Archipels norrois. Orcades, Shetland et Hebrides dans le monde viking. Göppingen, Kümmerle Verlag.

Rendboe, L. 1987: Det gamle shetlandske sprog (NOWELE Supplement vol. 3). Odense, Odense Universitetsforlag.

Rendboe, L. 1993: Shetland's Hildina Ballad: Its Discovery and Further Discussion (PrePublications of the English Department of Odense University 68). Odense, Odense Universitetsforlag.

Rendboe, L. 2007: The Development of Shetland Norn. NOWELE 50/51: 183-247.

Solberg, O. 2008: The Scandinavian Medieval Ballad: From Oral Tradition to Written Texts and Back Again. In E. Mundal \& J. Wellendorf eds. Oral Art Forms and their Passage into Writing. Copenhagen, Museum Tusculanum Press: 121-133.

Syndergaard, L. E. 1995: English Translations of the Scandinavian Medieval Ballads. An Analytical Guide and Bibliography. Turku, The Nordic Institute of Folklore.

Thorsen, P. 1954: The Third Norn Dialect — That of Caithnes. In W. D. Simpson ed. The Viking Congress, Lerwick, July 1950. Aberdeen, University of Aberdeen: 230238.

Thuren, H. 1902: Tanz, Dichtung und Gesang auf den Färöern. Sammelbande der Internationalen Musikgesellschaft 2: 222-269.

Towrie, S. 2008: Norn Ballad Deserves Recognition, Says Linguist. The Orcadian 3 January 2008: 12 .

Wylie, J. \& D. Margolin 1981: The Ring of Dancers. Images of Faroese Culture. Philadelphia, University of Pennsylvania Press.

\author{
Author's address \\ Department of Social Anthropology \\ University of Bergen \\ Nygårdsgaten 124 \\ 5008 Bergen \\ e-mail: marca@stpaulgymnas.no
}

received: 18 June 2019 revised version accepted: 17 June 2020 